\title{
Borislav Mikulić
}

Lazareti metafilozofije: metafizika i metoda

u autoterapijskim

diskursima filozofije

Metafilozofija i pitanja znanstvene metodologije, ur. B. Mikulić i M. Žitko,

Zagreb: Filozofski fakultet Sveučilišta u Zagrebu, 2020, str. 15-81

EMAIL: bmikulic@ffzg.hr 


\section{SAŽETAK}

Rad predstavlja uvodni historijski pregled i nacrt sistematskog razumijevanja pojma metafilozofije u širokom rasponu od njegove moderne konceptualizacije $\mathrm{u}$ analitičkoj filozofiji jezika (Lazerowitz), motivirane Freudovim pojmom metapsihologije, preko kritičkog modela metafilozofije kod Adorna i kritike postmodernih antifilozofija (Badiou) natrag do romantičke filozofije jezika (Hamann, Herder) i Aristotelova shvaćanja filozofije kao metode. Rad preispituje rašireno uvjerenje da je neologizam metafilozofija skovan $\mathrm{u}$ analogiji sa starijim umjetnim terminom metafizika i da ga treba ispravno razumijevati kao posebnu vrstu refleksije filozofije o samoj sebi ili kao filozofiju drugog reda. Takvo je shvaćanje visoko problematično utoliko što cijepa metadiskurse o filozofiji na izvanjske (npr. kulturalne, psihoanalitičke, sociološke, političke) i unutrašnje po kojima je metafilozofija samo prošireni diskurs iste filozofije prvog reda. Rezultat toga je da takvo razumijevanje metafilozofije $u$ analitičkoj tradiciji danas proizvodi uglavnom preskriptivne ili normativne prikaze filozofije i uvode u filozofiju (Rescher, Williamson, Horwitch) ili čak pokušava uspostaviti novu disciplinu unutar filozofije poput ontologije, etike i dr. (Overgaard i dr.). Suprotno tome, u novijoj "kontinentalnoj" tradiciji, sâm pojam metafilozofije rastočen je raspravama koje nastavljaju starije antifilozofske tendencije posthegelovskih filozofija od Feuerbacha preko Nietzschea i Kierkegaarda, Wittgensteina, Freuda i Lacana, uključujući Badiouove pokušaje reintegracije antifilozofije u metafilozofiju. Na takvoj širokoj i složenoj pozadini, pokušavam precizno istražiti kako neki metakoncepti - lingvistički pojam metajezika u smislu poietičke funkcije prirodnog jezika, pojam metakritike, kakav je u romantičkoj filozofiji jezika afirmirao J. G. Hamann protiv Kantova "transcendentalnog purizma uma”, termin méthodos, koji se kod Platona i Aristotela često zamjenjuje izrazom metiénai (tragati) - daju skupa adekvatniji model reprezentacije "prirodne" pripadnosti metafilozofije filozofiji nego metafizika. 
Lazarets of Metaphilosophy. Metaphysics and Method in Auto-Therapeutic Discourses of Philosophy

The paper attempts to give both an introductory historical survey and an outline of a systematic understanding of the notion of metaphilosophy in the wide range between its conceptualization in the modern analytic philosophy of language (Lazerowitz), which is clearly motivated by Freud's concept of metapsychology, through models of metacritique in Adorno and the critique of postmodern antiphilosophies in Badiou, back to the romantic philosophy of language (Hamann, Herder) and to Aristotle's conception of method. The paper questions the widespread assumption that the neologism metaphilosophy is forged in analogy to the older artificial term metaphysics and that it should properly be understood as a kind of distanced, second-order reflection of philosophy on itself. However, this understanding has proved highly problematic since splitting meta-discourses about philosophy into those from without (e.g. cultural, psychoanalytic, sociological, political) and those from within, according to which metaphilosophy is a mere extension of the discourse of first-order philosophy. As a result, immanentist approaches to metaphilosophy in the analytic tradition nowadays produce mostly prescriptive or normative introductions to philosophy (Rescher, Williamson, Horwitch) or try to establish a new discipline within philosophy parallel to ontology, ethics etc. (Overgaard et al.). By contrast, in recent 'continental' philosophy, the very idea of philosophy is dissolved by anti-philosophical debates extending the old trends of post-Hegelian trans-philosophies from Feuerbach and Marx through Nietzsche and Kierkegaard to Wittgenstein, Freud, and Lacan, including Alain Badiou's attempts to reintegrate antiphilosophies into metaphilosophy. On such a vast background, I try to scrutinize how some metaconcepts - the linguistic notion of metalanguage in the special sense of the poetic function of natural languages, the romantic philosophy's notion of metacritique, conceived by J. G. Hamann against Kant's "transcendental purism of Reason", and the Greek notion of method, often explained or substituted by metiénai (pursuing) in Plato and Aristotle - generate, if taken together, a more real model of representing how metaphilosophy belongs to philosophy more "naturally" than metaphysics does. 


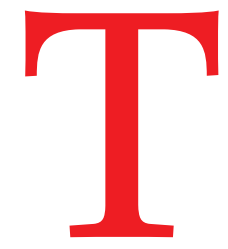

ema metafilozofije danas možda iznenađuje svojim masivnim prisustvom u suvremenoj analitičko-filozofskoj produkciji, no s obzirom na porijeklo i narav odnosa između analitičke filozofije prema ostatku filozofskih praksâ i kulturâ početkom 20. stoljeća, nema previše mjesta za čuđenje. ${ }^{01}$ Ako je igdje filozofija počela kardinalnim pitanjem metafilozofije, što je valjana filozofija, a ne nekim "običnim" filozofskim pitanjem o svijetu, onda je to bila analitička filozofija. ${ }^{02}$ To nasljedstvo preuzela je analitička metafilozofija u najboljem uvjerenju da je prevladala "urođenu bolest" specifičnog tipa mišljenja pod imenom metafizike za koju se sâma filozofija uvijek nudila kao terapija nudeći nove modele metafizike pod imenom kritike i čineći tako termin metafizika možda najkontroverznijim pojmom u povijesti filozofije. Emblematična za tu nesretnu povijest pojma metafizika svakako je kritika čistog uma Immanuela Kanta, s reputacijom "razbijača metafizike", koji je upravo time ujedno položio temelj za "svaku buduću metafiziku". Analognu situaciju nalazimo kod najznačajnijeg novokantovca 2o. stoljeća, filozofa jezika i kulture Ernsta Cassirera, koji u drugačijem konceptualnom okviru, u svojoj epohalnoj Filozofiji simboličkih oblika iz 1920-ih, polazeći od dalekosežne distinkcije supstancijalnih i funkcijskih pojmova iz epohalnog iako kasno prepoznatog djela Substanzbegriff und Funktionsbegriff iz 1910., ponovo rastače "tradicionalnu, ontološku, dogmatsku metafiziku”, da bi, na osnovi znakovne relacije kao temeljne funkcije pripremio teren za rehabilitaciju metafizike. Ona se oslanja na dijalektičku koncepciju poietičke prakse kakvu nalazimo u neobjavljenim rukopisima iz 1930-ih, izdanim posthumno tek 1995. pod naslovom Metafizika simboličkih oblika ${ }^{03}$ Pritom je pravi kuriozitet

01 Za opsežnu i produbljenu diskusiju s bibliografijom analitičke i kontinentalne tradicije v. Joll 2017, "Metaphilosophy”. Također Moser 1999, "Metaphilosophy”; Cath 2016, "Metaphilosophy”. Za didaktički studij metafilozofskih tema v. Suber 1997-2000, "Metaphilosophy: Themes and Questions"; Ichikawa (ed.) 2019, "Metaphilosophy”.

02 Za normativan pristup metafilozofiji vidi osobito Williamson 2007, 2018, Rescher 2010, 2014. (Detaljnija diskusija u nastavku.)

03 Cassirer 2010 (1923), Philosophie der symbolischen Formen (v. programski stav str. 30); Cassirer 1995, Metaphysik der symbolischen Formen (o konceptu subjekta kao "dijalektički nužnog jedinstva" triju "bazičnih fenomena”- ja, voljnog djelovanja i djela - v. programski 127). Za ishodište v. Cassirer 1910, Substanzbegriff und Funktionsbegriff gdje analizira jezik kao "fundamentalnu stukturu" posebnih "relacijskih" znanosti, poput 
da Cassirer rehabilitira kritički pojam "metafizike" na jezično-filozofskim pretpostavkama dvojice "razbijača” Kantove kritike metafizike, J. G. Herdera i J. G. Hamanna, iako ne prepoznaje bliskost svoje nove metafizike simboličkog s njihovom "metakritikom". Vidjet ćemo da u tome neće biti jedini kao što ni samo neprepoznavanje srodstava u povijesti filozofskih ideja ne nalikuje toliko na jedinstvene slučajeve koliko na simptome dubljeg procesa filozofskih nepriznavanja pod krinkom amnezije. Otud, suprotno analitičkom optimizmu, čini se da tzv. "kontinentalna" ili hermeneutička tradicija, uzeta u najširem smislu toga izraza, istrajava u prebolijevanju "Anaksimandrove kletve" koja bdije nad svakom filozofskom teorijom, kako se svojedobno izrazio Theodor Adorno preuzimajući i kletvu i njezino prebolijevanje na vlastitu metakritiku. ${ }^{04}$ Filozofska terapija svijeta logosom oduvijek se čini zapravo kao obnavljanje bolesti, kao terapija terapije, takoreći. Otud nema previše mjesta za čuđenje ako Platonova metafilozofska "ljekarna" posluje jednako dobro i u kontinentalnoj filozofiji, iako možda s više glavobolje i amnezije nego analitička. ${ }^{05}$

\section{Metafilozofija, metapsihologija i "prirođena bolest" filozofije}

Prema vlastitim tvrdnjama, termin metafilozofija skovao je analitički filozof starije generacije i istaknuti wittgensteinovac Morris Lazerowitz, 1940-ih godina, "da bi se mogao nedvosmisleno referirati na specijalnu vrstu istraživanja koju je Wittgenstein opisao kao jednu od 'nasljednica' filozofije”, a prvi put je korišten 1942. u časopisu Mind. ${ }^{06}$ $\mathrm{Na}$ istome mjestu Lazerowitz definira metafilozofiju kao "istraživanje

matematike ili logike. Za novije vrednovanje Cassirerove "metafizike djela” v. npr. monografiju O. Schwemmer 1997, Ernst Cassirer, osob. IV. “Der Werkbegriff der Metaphysik der symbolischen Formen”, 197-220.

04 Adorno 1959, Zur Metakritik der Erkenntnistheorie.

05 Tako J. Derrida 1972, La pharmacie de Platon samo usput spominje dijalog Harmid (333), iako motiv doslovne glavobolje mladića željnog filozofije predstavlja uvod u rasprave o metaznanju. Istu gestu prešućivanja ponavlja i prema dijalogu Teetet kad u "enigmatskoj snazi" Platonove "metafore pisanja u dušu” (278b8) treba prepoznati/priznati ono što proturječi "fonocentričkom" čitanju Platonove teorije "tipova" nauštrb pisma (v. osob. 116 i.d.).

06 Vidi Lazerowitz 1970, “A Note to 'Metaphilosophy”: “The word has a brief history. It was coined by me in 1940 so as to enable me to refer unambiguously to a special kind of investigation which Wittgenstein had described as one of the 'heirs' of philosophy" (91). 
prirode filozofije čiji je glavni cilj doći do zadovoljavajućeg objašnjenja o odsutnosti neosporenih filozofskih tvrdnji i argumenata". ${ }^{77}$ Godinu dana kasnije, u sadržajno istovjetnoj, ali manje tehničkoj verziji definicije, koju nalazimo u monografskom članku "Metaphilosophy" u meksičkom časopisu Crítica, specijalni cilj takvog "novog polja” istraživanja filozofskih iskaza i argumenata opisuje se retorički bujnije kao "liječenje prirođene bolesti” same filozofije, koja svakim svojim aktom generira suprotnost svome cilju:

"Metafilozofija je istraživanje filozofskih iskaza s posebnim ciljem da se postigne zadovoljavajuće razumijevanje onoga što u njihovoj prirodi dopušta nelječiva neslaganja koja ih invarijantno prate.”os

Lazerowitz pritom primjećuje s određenom dozom žaljenja kako filozofi, usprkos neočekivanoj popularnosti novog polja istraživanja, izraslog na nekolicini ideja Ludwiga Wittgensteina, nažalost više preferiraju priču o metafilozofiji umjesto da se poduhvate metafilozofskog rada.$^{09}$ Međutim, njegova je definicija postala takoreći stajaćom formulom za shvaćanje metafilozofije $u$ analitičkoj tradiciji i upravo na izjednačavanju metafilozofije s jezično-terapeutskom analizom filozofskih iskaza izrastao je tokom druge polovice 20. stoljeća velik korpus metafilozofskih refleksija suvremene analitičke filozofije. ${ }^{10}$ Kako

07 Lazerowitz 1970: "Metaphilosophy is the investigation of the nature of philosophy, with the central aim of arriving at a satisfactory explanation of the absence of uncontested philosophical claims and arguments" (isto, kurziv moj).

08 Lazerowitz 1977, "Metaphilosophy”, 1: "Metaphilosophy is the investigation of philosophical utterances, with the special aim of reaching a satisfactory understanding of what in their nature permits the intractable disagreements which invariably attach to them." (Izvorno u Lazerowitz 1971, 3.) Vidjet ćemo da Lazerowitzov izraz attach kao i medicinski žargon u kritici filozofije ima dugu povijest, daleko dužu od 1940.

09 Lazerowitz 1977: "A new field of investigation called 'metaphilosophy', which has its roots in a number of revolutionary ideas of Ludwig Wittgenstein, is emerging, and beginning to attract attention. By and large, however, it would seem that philosophers prefer the word to the deed, for although the word 'metaphilosophy' has won unexpected popularity, the special investigation it was coined to refer to has been more talked about than practiced."

10 Vidi Lazerowitz 1964, Studies in Metaphilosophy i prikaz u Gale 1965. Recepcija se nastavlja u rasponu od prihvaćanja (Ambrose 1967), preko analize odnosa metafilozofije i filozofije jezika (Rorty 1967) do primjene 
vidimo, posljedica toga razvoja je i sâm časopis Mataphilosophy, pokrenut 1970. i posvećen tipičnim temama filozofije u analitičkoj tradiciji, ali također i širokom spektru autoreferencijalnih pitanja filozofije o "samoj sebi". "S vremenom, povlašteno mjesto logičke filozofije jezika u tako shvaćenoj metafilozofiji sve više preuzima teorija filozofskog znanja u različitim vidovima, što dobro karakterizira sljedeća tipična fomulacija kojom se danas definira metafilozofija:

"Metafilozofija je filozofski studij same filozofije kao što je filozofija jezika filozofski studij jezika, a filozofija vremena filozofski studij vremena. Središnja pitanja metafilozofije tiču se samog filozofskog istraživanja ili epistemologije filozofije." 12

Takav razvoj metafilozofije potvrđuje se i na idejno-povijesnim istraživanjima o klasičnim mjestima filozofije, od moderne kod Kanta do antičke kod Platona. ${ }^{13}$ Pritom se metafilozofija identificira kao izričita refleksija o kategorijama: kod Kanta ona leži u novom, ne-aristotelovskom smislu termina metafizika koji sad ne označava umnu teoriju čistog bića kao bića, nego "bavljenje uma samim sobom", istraživanje "uvjeta mogućnosti svake znanosti" i novu "raspravu o metodi".

Međutim, koncept metafilozofije kakav nalazimo kod Lazerowitza nije izvor idile analitičke filozofije u bavljenju sobom niti je prizor filozofske inventivnosti. Slikovita verzija njegove definicije iz 1971. daje osobito dobar uvid u to da se pojam zasniva na dvjema različitim, ali

na klasičnu tradiciju, modernu i antičku. Za noviji opsežan prikaz i raspravu o Lazerowitzevom ројти metafilozofije v. Reese 1990.

11 Vidi pregled razvoja časopisa u Bynum 2011, "Creating the Journal Metaphilosophy" te cijeli tematski blok The Future of Philosophy. Metaphilosophical Directions for the Twenty-First Century. Da je časopis rezultat jednog tematskog razvoja filozofije, a ne toliko ishodište, pokazuju i starije bibliografske reference na sam naslov (v. pregled u prilogu L. Veljaka, ovdje).

12 Ichikawa (ed.) 2019. Vidi također Williamson 2007, The Philosophy of Philosophy, osob. pogl. 7, 'Evidence in Philosophy'.

13 Vidi Griswold 1988, "Plato's Metaphilosophy", osob. 145-147. Iako je izričit cilj pokazati prisustvo metafilozofije kod Platona protiv uvriježenih uvjerenja u anglo-saksonskoj tradiciji o "naivnosti" Platonova filozofiranja, rad je i danas relevantan s obzirom na uvriježeno shvaćanje o tzv. spontanom karakteru metafilozofije u "kontinentalnoj” tradiciji naspram reflektirane analitičke. Vidi Joll $2017 \mathrm{i}$ raspravu u nastavku ovog rada. 
povezanim i problematičnim pretpostavkama u pozadini. Najprije, termin predstavlja, kako ga razumijeva Lazerowitz, analogon terminu metafizika, gdje se prijedlog metá čita u rekciji s akuzativom kao u frazi 'metà tà physiká', i sugerira neko stanoviše iza, iznad ili povrh filozofije koje nam omogućuje teorijski opredmećujući govor o filozofiji u cjelini. Takvo "metafizičko" shvaćanje leži, kako ističu neki suvremeni prikazivači, u osnovi pretpostavke po kojoj "neki filozofi uzimaju prepozicija metá u značenju o". ${ }^{14}$ Iako se pri tome naizgled radi samo o pitanju ispravnog prijevoda, riječ je o složenijem problemu objedinjavanja eksternalističkog i imanentističkog odnosa metafilozofije i filozofije koji se reflektira na filološkoj razini: sama pretpostavka suvremenih autora da se prijedlog metá može uzimati u značenju o implicira da se u pozadini već odvila zamjena prijedloga metá prijedlogom perí s genitivom, što je, kako ću kasnije prikazati detaljnije, jezično posve pogrešno i konceptualno neodrživo.

No, i bez takve filološke analize, u međuvremenu možemo protiv Lazerowitzove dijagnoze o "nepostojanju neosporenih stavova u filozofiji" konstatirati da shvaćanje metafilozofije na matrici termina i pojma metafizika posve sigurno pripada u "osporene tvrdnje" filozofije, kako to pokazuje sâma povijest analitičke filozofije, odnosno povijest njezinog "nasljeđivanja" filozofije. Ono se vidi ili iz unutar-filozofske perspektive, poput logičke kritike jezika filozofije kod "ranog” Wittgensteina iz Traktata, ili pak s izvan-filozofskog gledišta, poput kritike filozofije sa stanovišta analize svakodnevnog jezika kod "kasnog" Wittgensteina iz Filozofskih istraživanja. Danas vodeći postanalitički teoretičari metafilozofije i metodologije, poput Nicholasa Reschera i Timothyja Williamsona, ne odbacuju samo taj "metafizički smisao" pojma nego i sâm termin metafilozofija. ${ }^{15}$ No, to se metafizičko "nasljeđe” u samom modelu filozofske teorije, koje totalizira i opredmećuje i samu filozofiju, čini otpornim i stabilnim. Štoviše, kako ću još pokazati, ono predstavlja terminološku i pojmovnu matricu samorazumijevanja metateorije i u drugim disciplinama na rubu ili izvan filozofije,

14 Engl. about: v. raspravu u Joll 2017; također Reese 1999, "Morris Lazerowitz and Metaphilosophy”, 28.

15 Vidi Williamson 2007, ix: "I also rejected the word 'metaphilosophy' (...) metaphilosophy sounds as though it might try to look down on philosophy from above, or beyond". Također Williamson 2018, Doing Philosophy gdje posve izbjegava termin metafilozofija. Slično formulira i Rescher 2007, Interpreting Philosophy, 49-50, 54; Rescher 2014, Metaphilosophy, xii. 
poput metamatematike. ${ }^{16}$ No, pravo porijeklo Lazerowitzova termina i razumijevanja metafilozofije leži, po mome mišljenju, u terminu i pojmu metapsihologija koji on sâm, prema mome uvidu, nije nigdje izravno imenovao.

Na nju ukazuju neizravno, ali dovoljno jednoznačno, već retorika Lazerowitzove plastične definicije metafilozofije, a također i njegovo tematsko bavljenje Wittgensteinom i Freudom. ${ }^{17}$ Ta dva elementa čine dovoljno vjerodostojnom pretpostavku da Lazerowitz nije skovao termin metafilozofija autonomno i izravno iz filozofije, analogno terminu metafizika, iako svi njegovi komentari sugeriraju upravo to, nego ga je prenio u filozofiju preslikavanjem Freudova termina i pojma metapsihologija. Premda Lazerowitz nigdje ne priznaje taj izvor svoga termina metafilozofija, pa čak također ni u jednom od radova koji se izravno ili neizravno tiču Freuda uopće nigdje ne imenuje termin metapsihologija niti upućuje na njega, izdaje ga upravo prešućivanje koje ne može biti očigledniji primjer poricanja stvari kroz obilje govora koji je čini odsutnom. ${ }^{18}$ Riječ je o poricanju u istovjetnom psihoanalitičkom smislu kakav sâm Lazerowitz pripisuje Wittgensteinovu osobnom odnosu prema psihoanalizi.

Dakako, ovu pretpostavku podržava, i čini donekle trivijalnom, već sâma dvostruka posrednička uloga Wittgensteina između Freuda i Lazerowitza, ali trivijalnost je samo prividna. S jedne strane, Lazerowitz izravno povezuje metafilozofiju s "nizom revolucionarnih ideja Ludwiga Wittgensteina”; s druge strane, za Wittgensteina navodi kako je, nakon početnog oduševljenja, a potom odbacivanja psihoanalize, nesvjesno interiorizirao psihoanalizu i postao takoreći "psihoanalitičarem filozofije":

16 Za paralelizaciju metafilozofije s metamatematikom v. Moser 1999, 562: "The distinction between philosophy and metaphilosophy has an analogue in the familiar distinction between mathematics and metamathematics." O važnosti analize matematičkih objekata u Wittgensteinovoj metafilozofiji v. Horwitch (2013), Wittgenstein's Metaphilosophy, osob. 1.3.

17 Lazerowitz 1977, pogl. II. "Freud and Wittgenstein”, 48-72.

18 Prizor takve komplikacije daje usporedba ranijeg časopisnog i kasnijeg knjižnog izdanja spisa "Metaphilosophy” gdje Lazerowitz za motto uzima citat kojeg nema u časopisu Crítica iz 1971. Citat iz Freuda glasi na engleskom: "When a delusion cannot be dissipated by the facts of reality, it probably does not spring from reality. Freud” (v. Lazerowitz 1977, pogl. I). 
"Kad je Wittgenstein prvi put saznao za psihoanalizu i čitao Freuda, bio je ispunjen divljenjem i poštovanjem. O Freudu je zapazio: 'Evo nekoga tko ima nešto reći'. Kasnije se okrenuo protiv psihoanalize i odbacio je kao štetnu mitologiju. Međutim, desilo se nešto značajno što bi se moglo opisati kao skriveni, pomaknuti povratak odbačenog." ${ }^{19}$

Međutim, pravi problem o kojem je ovdje riječ ne tiče se toliko komplikacije odnosâ kroz Wittgensteinovo postajanje psihoanalitičarem filozofije u poziciji pacijenta psihoanalize koliko između Lazerowitza i metafilozofije. Više od rečenoga na ovom mjestu govori komadić metateksta u dodatnoj bilješci gdje Lazerowitz naglašeno upozorava kako za Wittgensteinov stav prema psihoanalizi ne koristi izraz 'potisnut' (repressed), nego 'odbačen' (rejected). ${ }^{20}$ Retorički dobro zaokružen opis putanje Wittgensteinovog odnosa prema psihoanalizi od oduševljenja, preko odbacivanja do nesvjesne interiorizacije, jasno naznačuje da je fraza "povratak odbačenog" svakako pomno formulirana Lazerowitzova pretpostavka s obzirom na Wittgensteinov dokazani svjesni, prvo pozitivni, a potom negativni odnos prema psihoanalizi. Međutim, upravo ta korektnost oko očiglednosti - naime, oko Wittgensteinova eksplicitnog negiranja potrebe za psihoanalizom — predstavlja višak na Lazerowitzovu iskazu i govori više nego što iskazuje: naime, da Lazerowitz, birajući jedan od dvaju mogućih izraza za Wittgensteinov kasniji negativni odnos prema potrebi za psihoanalizom u svojoj filozofiji (odbacivanje umjesto negiranja), zapravo ispušta treći i pravi termin za psihonalitički opis "povratka odbačenog" kod Wittgensteina koje će ga učiniti "nesvjesnim psihoanalitičarem filozofije”. Taj treći i zaobiđeni izraz je 'porečeno' (denied). Poricanje, umjesto negiranja i odbacivanja, predstavlja u psihološkom smislu dinamički, u lo-

19 Lazerowitz 1977, "Freud and Wittgenstein", 28: "When Wittgenstein first learned about psychoanalysis and read Freud he was filled with admiration and respect. He remarked about Freud, 'Here is someone who has something to say'. Later he turned against psychoanalysis and rejected it as a harmful mythology. A remarkable thing, however, took place, which might be described as the hidden, displaced return of the rejected."

20 Lazerowitz 1977, 41 (bilj. 15): "It should be noted that I do not use the word 'repressed'. Wittgenstein rejected his need for psychoanalysis; it is not at all probable that he repressed it." Sâm Wittgenstein se implicitno referira na Freudove elaboracije o "potrebi za psihoanalizom" u drugim disciplinama, poput filozofije (v. Freud 1913). 
gičkom smislu naoko paradoksalan, a pojmovno dijalektički odnos potiskivanja kroz priznanje. Ono nije samo pojmovni ekvivalent za Lazerowitzovu frazu "povratak odbačenog" kod Wittgensteina, nego izražava najočiglednije, iako najneuhvatliivije, prisustvo prešućenog pojma metapsihologija и ројти metafilozofija, aluziju kroz masivne reference na Freuda u govoru o Wittgensteinu. Od takvog scenarija za analitičku filozofiju može biti gore još samo to da poricanje u psihoanalitičkom značenju termina doprinosi tome da Wittgensteinovo "nasljeđe filozofije u antifilozofiji” poprimi karakteristike Hegelovog "ukidanja" (Aufhebung): suprotnosti se ukidaju kroz uzdizanje na višu razinu koju reprezentira nešto treće. ${ }^{21}$

S navodnim privatno-psihološkim prevratom u teorijskim interesima Wittgensteina najuže je povezan drugi zajednički i teorijski moment njegovog posredovanja između Lazerowitza i Freuda: on se tiče terapijske funkcije jezika u meta-analizi kojoj Lazerowitz posvećuje ekstenzivan citat iz Freudove Autobiografije kako bi ukazao na funkciju “jezične terapije za izbjegavanje metafizike u Wittgensteinovim Filozofskim istraživanjima”.22 No, kako pitanje karaktera, funkcije i statusa svakodnevnog jezika kod Wittgensteina i kod Freuda obuhvaća velik broj tema, ovdje neću dalje ulaziti u Lazerowitzovo direktno prenošenje Freudove "terapije govorom" ("talking cure”) s analize neurotika, pjesnika i umjetnika na jezično-logičku analizu "nutarnjeg života filozofa”. ${ }^{23}$ Umjesto toga zadržat ću se na drugoj posredujućoj instanci između metafilozofije i metapsihologije. Nju čini, po mome mišljenju, ne posve osviještena uloga pojma metafizike u konceptalizaciji obaju pojmova, i metafilozofije i metapsihologije. Čini se da gravitacijska sila metafizike ili, možda bolje rečeno, njezin “opijatski” karakter, djeluje

21 Drugi najbliskiji primjer psihoanalitičkog poricanja dokumentira, prema mome mišljenju, sâm početak Wittgensteinovih Filozofskih istraživanja, gdje teoriju jezika kakvu je sam zastupao u Traktatu kritizira kod Sv. Augustina, koristeći ga takoreći kao zamjenskog dječaka za šibanje (Prügelknabe). Vidi Wittgensten PhU, $\mathbb{S} 1$ (njem-engl. izdanje 2009, 5).

22 Vidi Lazerowitz 1977 (II. Freud and Wittgenstein), 22-23, te (III. Language and Necessity), 74 (bilj. 25).

23 Lazerowitz 1977, 22, 25. Ipak vrijedi istaknuti da Wittgensteinovo odbacivanje psihoanalize kao "mitologije" indicira, s jedne strane, teorijsku tendenciju izlučivanja njezine jezično-metodološke strane, a s druge strane, poricanje $i$, kasnije, ograničeno priznanje vlastite homoseksualnosti (v. Rowe 2007). 
podjednako i na analitičkog filozofa Lazerowitza kao što se čini da je djelovala na analitičkog psihologa Freuda. ${ }^{24}$

Termin metapsihologija prvi se put javlja u privatnoj korespondenciji s Fließom iz 1896., a u kasnijim tehničkim spisima iz razdoblja 1913-1917. bit će korišten u užem značenju kao "studij onih pretpostavki na kojima se gradi sustav psihoanalitičke teorije". ${ }^{25}$ Ta promjena ne umanjuje osebujnost prvog javnog korištenja pojma u slavnom spisu “O psihopatologiji svakodnevnog života" [Zur Psychopathologie des Alltagslebens] iz 1905., gdje ga Freud jasno izvodi iz pojma i imena metafizika. Metapsihologija se sastoji

“(...) u konstrukciji nadosjetilne stvarnosti koja putem znanosti treba biti preobražena natrag u jednu psihologiju nesvjesnog. Mogli bismo se osmjeliti (...) da metafiziku preobrazimo u metapsihologiju."26

Bliskost i razlika između jednog i drugog očituje se u Freudovoj formulaciji na putanji dvostrukog, sukcesivnog, ali nasuprotnog toka prevođenja, kojom će se nadosjetilna stvarnost mita (ideje raja, istočnog grijeha, Boga, besmrtnosti), koja je već prošla kroz prevođenje u pojmovnik metafizike, prevesti natrag u konkretni predmet psihologije nesvjesnog, u predmet znanosti koji zadržava karakter mitskog. Racionalna metafizika je, kao prijevod mitskog pojmovnika, analogna mitskom svijetu neurotika: svo troje počiva na nadosjetilnoj stvarnosti koja će ih učiniti predmetom nove psihologije. Ta putanja, koja opisuje znanstvenu ulogu i značenje metapsihologije nakon i slijedom metafizike, iskazuje ujedno i netematizirano, takoreći samo asocijativno i su-pomišljeno, nasljeđe metafizike u metapsihologiji: njezin racionalizirajući posao u odnosu na mit, kakav će metapsihologija preuzeti u svoj znanstveni

24 Lazerowitz 1977, 1: "One philosopher has declared that on the metaphilosophical view I have developed over the years, metaphysics is 'the mescalin of the elite', which would make understandable the general attitude towards the meta-investigation of philosophy”.

25 Prvi podatak odnosi se na pismo Wilhelmu Fließu od 12. veljače 1896., a drugi na spise iza 1913. Vidi "Metapsychologie”, Historisches Wörterbuch der Philosophie (W. Loch), Bd. 5, 1298-1299; također Holt (2002),

"Metapsychology" u: The Freud Encyclopedia, 337-338.

26 Usp. Freud 1905, GS Bd. IV, 288: “(...) in der Konstruktion einer übersinnlichen Realität, welche von der Wissenschaft in eine Psychologie des Unbewußten zurückverwandelt werden soll. Man könnte sich getrauen (...), die Metaphysik in Metapsychologie zu verwandeln.” (Prijevod moj, kurzivi u izvorniku.). 
posao vraćanjem nadosjetilnog u empirijski materijal, iako će predmetu znanosti unutar same znanosti pridati "mitski", pripovjedni, karakter - nesvjesno. To je ono što proizlaženje ili odnos sukcesivnog prevođenja metapsihologije iz metafizike čini paralelnim odnosom disciplinâ. Metapsihologija dobiva, gledano vremeneski i topički, isti položaj prema metafizici kakav je metafizika u poretku znanja dobila prema fizici. Metapsihologija zauzima položaj meta-metafizike ili meta-mitologije, s kojeg će moći opredmetiti cijelu filozofiju i postati eksternom (psihoanalitičkom) kritikom njezinih diskurzivnih izvora. ${ }^{27}$

Kako je spomenuto, Freud je tu topičku analogiju metapsihologija-metafizika, dobivenu gotovo slučajnim retoričkim efektom - glasovnom asocijacijom (asonancom) - $\mathrm{u}$ aktu teoretizacije, učvrstio tek desetak godina kasnije na terminološkoj razini, primjerice $u$ spisu "Nesvjesno" [Das Unbewußte] iz 1913. i drugim radovima iz razdoblja 1913-1917. Uzimajući metapsihologiju najprije kao drugo ime ili sinonim za psihoanalizu, Freud sužava značenje termina na njezino teorijsko utemeljenje i na radikalni zaokret u svijetu znanosti. Osim toga, koristit će izraz metapsihologija i kao urednički termin na metatekstualnoj razini, poput naslova spisa "Metapsihološka dopuna učenju o snovima” [Metapsychologische Ergängzung zur Traumlehre] iz 1916. gdje izričito spominje svoj raniji plan da sabere radove pod naslovom "Metapsihologija". 28

Odatle s dovoljnom jasnoćom vidimo da opći pojam ili predodžba 'metafizike' iznutra i meta-znanstvena, sustavno-teorijska refleksija psihologije kao racionalne metamitologije izvana, isporučuju model

27 Za jedan od ranih značajnih radova koji na primjerima anglosaksonske filozofije i psiholoških teorija 19. i 20. stoljeća podvrgava psihoanalizi sam filozofski diskurs o principima, a ne privatne biografije filozofa, v. D. Feuer 1959. Vidi noviju raspravu Clemens 2013.

28 Vidi sada odjeljak Metaphychologie i uredničku bilješku GS Bd. V, 432. Sam Freud 1916, 520 (bilj. 1) navodi: "Namjera je te serije objašnjenje i produbljenje teorijskih pretpostavki koje bi se mogle postaviti u temelj jednog psihoanalitičkog sustava”. Pritom je Freud posve jasan u pogledu "još nesigurnog, opipavajućeg karaktera takvog metapsihološkog istraživanja” ( 533 , bilj. 2). Za mijene Freudova shvaćanja metapsihologije v. Brenner (1980), "Metapsychology and Psychoanalytic Theory"; također Assoun 2013, La métapsychologie (osob. 1-10, 11-27); sa stanovišta neuropsihoanalize v. Boag 2017, Metapsychology and the Foundations of Psychoanalysis (osob. Introduction, 4-12, te pogl. 1. The metaphysics of metaphsychology). 
za razumijevanje metafilozofije odozgo. ${ }^{29}$ Premda je takvo čitanje rašireno i čini se na prvi pogled intuitivno prihvatljivim, budući da sadrži moment teorijske objektivacije znanstvenog posla, koja je u svakom predmetnom istraživanju prirodan i samorazumljiv postupak, ono je postalo sporno u postanalitičkoj metafilozofiji upravo zbog pozadinske konceptualne veze s metafizikom koja je otuđuje i postavlja iznad same filozofije: metafilozofija se po svome autorefleksivnom, samoopredmećujućem i autoracionalizirajućem karakteru mora uzeti kao sastavni dio filozofije, a ne kao pozicija iznad ili odozgo (Williamson). Otud ne čudi da se sâmo njezino ime ili izbjegava ili deklarativno odbacuje i zamjenjuje: 'metafilozofija' je sada filozofija filozofije, disciplina drugog reda u odnosu na filozofske doktrine prvog reda. ${ }^{30}$

Sličan razvoj možemo zamijetiti i u analitičkoj metapsihologiji gdje nerazriješeni dvojni karakter nasljeđa metafizike izaziva glavobolje u samom pojmu metafilozofije. Tako P-L. Assoun, referirajući se na Freudovu formulaciju iz 1905. o ulozi metafizike kao konceptualnog posrednika od mitologije ka psihologiji i metapsihologiji, nastoji naknadno precizirati smisao formulacije. Međutim, u predgovoru za 2. izdanje knjige, ukazuje preventivno (i ispravno) na dvostruku upotrebu prepozicije metá u značenju 'pored' i 'iznad' te zaključuje: "Pozvanje metapsihologije sigurno nije to da postane metafizika psihologa". Počivajući dakle na višesmislenosti prefiksa meta- u navedenim i drugim sličnim složenicama, metastanovište se pokazuje rascijepljenim

29 U čudnovatom skladu činova prešućivanja, Assoun nigdje ne spominje izraz metafilozofija ni ime Lazerowitza. Historijski rječnik filozofije također ne navodi natuknicu metafilozofija. Zauzvrat, objektni pojam filozofije, poput metafizike ili filozofije znanosti, sastavni je dio prikaza metapsihologije, v. Boag (2017), "Metapsychology and Philosophy”, 8-10.

30 Vidi formulacije u Rescher 2007, 49-51, 53-54: "What the proper mission of philosophy is is in fact one of the definitive and most significant issues of the field. And this means that metaphilosophy is a part and parcel of philosophy itself" (51), "second-order discipline" (105). Isto u Rescher 2010, 17-18, Rescher 2014, xi-xii. Također i Williamson 2007, ix: "The philosophy of philosophy is automatically part of philosophy, just as the philosophy of anything else is."

31 Assoun 2013: "La métapsychologie n'a certes pas vocation à devenir la métaphysique du psychologue”, 119-120 (v. i predgovor str. 6). Međutim, kako smo vidjeli, sam Freud ju je, premda neodlučno, shvatio u tom smislu: metapsihologija je usmjerena na predmet koji je smješten iza područja psihologije a ona je teoretizacija principa kliničke psihoanalize, upravo kao Aristotelova prva filozofija u odnosu na fiziku. 
u ishodištu kao što će biti upitno u svome rezultatu. Ono projicira nezavisno i neutralno nad-stajalište nakon ili povrh filozofije s kojeg svi akteri metadiskursa - kako filozofi poput logičara i epistemologa tako i nefilozofi, poput lingvistâ, psihoanalitičara, kulturnih teoretičara i kritičara, antropologa i sociologa — još jednom teorijski opredmećuju diskurs koji već predstavlja teorijski prijevod nekog mita. ${ }^{32}$

No, usprkos dopadljivosti u pokušajima imanentističkog rješenja metafizičkih aporija u imenu metafilozofije kod postanalitičkih autora i tendenciji ka zamjeni termina metafilozofija frazom filozofija filozofije, iz povijesti ideja filozofije o samoj sebi znamo da taj stav nije ni nov ni tako samorazumljiv, pa niti tako "antimetafizički", kako se čini, niti pak da se zamjenom termina bitno mijenja opredmećujući odnos metafilozofije prema filozofiji. Naprotiv, s izrazom filozofija filozofije on postaje još očigledniji, iako u argumentaciji prolazi nezamijećeno.

S jedne strane vidimo, stav imanentizma je i u analitičkoj tradiciji rezultat dubinske polemike u rasponu od rane analitičke do postanalitičke filozofije oko naravi odnosa između disciplinâ prvog i drugog reda, što se uvijek iznova pokazuje kao kronični i akutni problem kod filozofije jezika. Aktualni pojam metafilozofije kod Reschera, Williamsona i drugih postanalitičara sadrži negaciju ranijeg, jezičnoanalitičkog koncepta metafilozofije kakav nalazimo kod Lazerowitza, koji sa svoje strane počiva na Wittgensteinovoj negaciji tradicionalne filozofije koja je "ukida" tako da održava njezino nasljeđe. Drugim riječima, imanentizam - ili zahtjev za imanentizmom metafilozofije-i-filozofije - $\mathrm{u}$ aktualnom pojmu metafilozofije alias filozofije filozofije rezultat je negacije negacije, pa otud ne čudi da se novije rasprave unutar analitičke tradicije dadu prevesti natrag u glavne tokove "kontinentalne" filozofije, baš kao što Freud vidi metapsihologiju kao prijevod metafizike u racionalnu metamitologiju putem znanosti.

No, kako ćemo vidjeti još pobliže, imanentistički zahtjev da metafilozofija bude sastavni dio filozofije, ili filozofija filozofije, nije zbog toga i konačni sretni kraj u priči o metafilozofiji! Osim što je rezultat burne unutarfilozofske polemike, taj zahtjev se prethodno,

32 O oscilacijama u smislovima izraza kod samog Lazerowitza između about, beyond i in v. Reese 1990, 28-34 (28): "The double usage leaves a problem of determining how 'about' and 'beyond' interrelate in the definition and 'in' philosophy (...) in Lazerowitz' analysis the word cannot be used in the sense of 'beyond'.' Vidi detaljniju filološku raspravu kasnije u ovom radu. 
već u samom polazištu, razbio o nejedinstvenost pojma filozofije kakva je prati od historijskih početaka do suvremenosti. Hegelovski rečeno, sâm imanentizam je samo zakrpano stanje jedne napukline. Stoga, uz dozu patetike možemo reći: stav o imanenciji metafilozofije-u-filozofiji kao da nosi breme davnog Sokratovog pitanja, što bi uopće trebalo biti znanja znanja ili spoznaja spoznaje, a da već nije određeno predmetom na koji se odnosi, tj. znanjem prvog reda. ${ }^{33}$ Što bi, dakle, metafilozofija uopće trebala biti ako ne neka filozofska refleksija uopće ili neka njezina posebna grana?

No, na sreću, pojam filozofije "prvog reda" tako je nejedinstven da to ne pogađa samo različitost i nesvodivost tipova mišljenja o svijetu koje nazivamo općim imenom filozofije, nego također i njihova samorazumijevanja. Čini se da nema samo svaka filozofija svoju metafilozofiju, nego također i svoj pojam metafilozofije, tj. meta-metafilozofiju.

\section{Imanentna izvanjskost: metajezik i njegove funkcije}

Sve rečeno isporučuje dovoljno razloga za uvid da definiranje metafilozofije u suvremenoj analitičkoj filozofiji preko jezične analize nije reduktivno samo idejno-historijski nego i konceptualno. Naime, čak ako metafilozofiju shvatimo sukladno mijenama u analitičkoj tradiciji, kao jezično-logičku kritiku ili epistemološki i metodološki samoopis filozofije, takav internalizam kritike, u kojem filozofija jasno dobiva status svog vlastitog objekta iz jednog posebnog unutarteorijskog kuta, nosi nekoliko problematičnih aspekata koji se više ili manje vidljivo ponavljaju u prikazima metafilozofije i njezinih sadržaja.

Jedan takav aspekt upravo je predmetno određenje metafilozofije, $\mathrm{u}$ analogiji s predmetnim definiranjem dijelova filozofije, prema područjima ili sektorima stvarnosti na koja se odnosi, poput "filozofije bilo čega” (Williamson). Neposredna posljedica toga je velik opseg preklapanja metafilozofskih pitanja s klasičnim unutar-filozofskim temama epistemološkog i metodološkog karaktera, što u konačnici ili potpuno despecifira metafilozofiju ili je svodi na još jednu unutarfilozofsku disciplinu. O paradoksu despecifikacije metafilozofije, usprkos emfatičnom nastojanju oko toga pojma, rječito govori razvoj u publikacijama možda najistaknutijeg autora, Nicholasa Reschera,

33 Radi se o pitanju iz dijaloga Harmid, zbog kojeg se taj dijalog smatra najkontroverznijim od tzv. ranih ili sokratičkih dijaloga (v. moj prilog

"Nijekanje metaznanja”, ovdje). 
koji je već svoju raniju monografiju Philosophical Dialectics. An Essay On Metaphilosophy iz 2006. nazvao "ne samo panoramom metafilozofskih pitanja nego i teorijom metafilozofije", iako nigdje u knjizi ne definira pojam metafilozofije, a sâm termin upotrebljava jedino na tome jednom mjestu. ${ }^{34}$ Ambiciji jedne teorije metafilozofije rječitije izlazi u susret njegova kasnija monografija Metaphilosophy. Philosophy in Philosophical Perspective iz 2014., danas valjda najcitiranija i prva referenca svih prikaza i rasprava o metafilozofiji, premda se po svojim sadržajima gotovo posve preklapa s ranijim studijama, tako da je i ovdje više riječ o "panorami” tipičnih filozofskih problema kakve poznajemo od Aristotelova Organona i metodološkom prikazu filozofije nego o teoriji metafilozofije. Na kraju, čini se da metafilozofsko stanovište kod Reschera postaje jednako "implicitno" i usmjereno na "vlastiti filozofski posao", kakvo pripisuje tradiciji i previđa kod Nozika, tako da sâma metafilozofija i kod svog danas najprominentnijeg zagovornika ponovo postaje, i protiv njegove volje, ono što je oduvijek bila: "siromašna i zanemarena rođakinja filozofije"."

$S$ druge strane, o svođenju metafilozofije na jednu unutarfilozofsku perspektivu govore dijagnoze da ni filozofija jezika u samoj analitičkoj tradiciji nije zadržala karakter metafilozofije, nego je, kako u pogovoru za drugo izdanje zbornika Linguistic Turn ustvrđuje Richard Rorty, samo zamijenila jedan medij reprezentacije svijeta drugim, iskustvo jezikom, i postala tek još jedna u nizu disciplinâ filozofije. ${ }^{36}$ Već takav

34 Vidi Rescher 2006, viii: "not only a panorama of metaphilosophical issues but also a theory of metaphilosophy”; slično i u Rescher 2010. Za takav totalni imanentizam Rescher se poziva na Roberta Nozika iz Philosophical Explanations: "A metaphilosophy will be part of a total philosophical view rather than a separate neutral theory above the battle" (Nozik 1981, 19; v. Rescher 2007, Interpreting Philosophy, 54, bilj. 4). Međutim, Nozik koristi pojam metafilozofija i metafilozofski u smislu vlastite refleksije o filozofskim pojmovima $(58,114)$, uklj. vlastiti "metafilozofski instinkt" (558). Upravo taj moment Rescher je prethodno proglasio manjkavim budući da je "non self-detached", usmjeren na “own philosophical business".

35 Rescher 2007, Preface: "Metaphilosophy is philosophy's poor and neglected cousin. Philosophers are on the whole too busy doing philosophy to take time to stand back and consider reflectively how the project itself actually works."

36 Rorty 1992, 373: “Twenty Five Years After”: "But I was still, alas, attached to the idea that there was something called 'linguistic method in philosophy'. I now find it impossible to isolate such a method [...] So, inso- 
rezultat dovoljan je za skepsu prema općem vjerovanju u analitičkoj kulturi da je metafilozofija u "pravom značenju pojma" istoizvorna s nastankom analitičke filozofije jezika početkom 20. stoljeća, koja, od Wittgensteina nadalje, polazi od pretpostavke kako su problemi filozofije zapravo problemi njezinog jezika i da ih treba "liječiti" metodom jezične analize. Vidimo da se takvo polazište stubokom promijenilo kroz zamjenu jezične analize epistemologijom filozofije. Međutim, ono je već prethodno rascijepilo i sâm jezično-analitički koncept metafilozofije na dvije nesvodive inačice, kroz dvije sukcesivne faze jezične metafilozofije, koje i intelektualnu biografiju Wittgensteina cijepaju na dva dijela: prvo na logičko čišćenje filozofije od prirodno-jezičnih besmislica te potom na refleksiju o upotrebi termina u svakodnevnom jeziku. ${ }^{37}$

Dodatni, prividno izvanjski aspekt jest taj da se metafilozofija shvaća, gotovo u pravilu prešutno i samorazumljivo, prema porijeklu svojih pitanja iz jedne od kultura filozofije, analitičke, pragmatičke ili tzv. "kontinentalne". Ta posve rijetko tematizirana okolnost u suvremenoj analitičkoj metafilozofiji sugerira da sâm pojam metafilozofije zapravo nije samostalan filozofski koncept, $i$ to ne samo zato što je automatski i neizbježno sastavni dio filozofije i pripada u "totalno gledište filozofije” (Rescher). Iako je već time izložen redundanciji, prijeti mu ista sudbina višeznačnosti, mnogostrukog iskazivanja i polemičnosti kao i pojmu sâme filozofije. ${ }^{38}$ Otud, premda smo tek na početku refleksije o metafilozofiji, čini se da s dosta rezignacije možemo sumirati: ako predmet metafilozofije ostaje, kako ga određuje Lazerowitz, "priroda filozofskih iskazâ koja dopušta nelječiva neslaganja kao njihov prirođeni invarijabilni dodatak", onda se posebnost metafilozofije u odnosu na filozofiju može ogledati još samo u tome da ona kao filozofija drugog reda, čak i pod vidom imanencije - tj. ostajući unutar "totalnog polja filozofije", "unutar bitke” (Nozik) — eksplicitno izražava

far as the linguistic turn made a distinctive contribution to philosophy I think that it was not a metaphilosophical one at all”.

37 Za dva glavna postupka jezične terapije na kojima, prema općem slaganju, počivaju dvije faze u Wittgensteinovoj biografiji i povijest analitičke tradicije uopće, v. raspravu u Hacking 1975. Za integralno viđenje Wittgensteinove metafilozofije v. iscrpnu monografsku studiju u Horwitch 2013; također Gakis 2012.

38 Za ideje o teorijskoj neutralnosti i jedinstvenosti metafilozofije naspram različitosti filozofijâ v. pregled i raspravu o novim doprinosima domaćih autora u Veljak (ovdje). 
prešutni sektaški karakter filozofije prvog reda dok se prepoznaje u doktrinarnim sadržajima njezinih poddisciplinâ. Metafilozofija bi se tako, za razliku od razlikâ među filozofijama u predmetnim teorijama prvog reda, sastojala u eksplicitnom samorazumijevanju jedne filozofije drugog reda naspram (ili čak protiv) samorazumijevanja neke druge filozofije drugog reda. Ako ostanemo samo unutar analitičke kulture filozofije, mogli bismo razlikovati barem tri filozofije drugog reda: Lazerowitzovu, Rortyijevu i Rescherovu. Još uže gledano, već kod Wittgensteina možda možemo govoriti o dvije različite metafilozofske koncepcije iako na zajedničkoj jezično-filozofskoj osnovi, logičkoj i pragmatičkoj. No, takav polemički pojam metafilozofije, koji očito baštini polemički karakter filozofije prvog reda, projicira ga na razinu drugog reda i izaziva proliferaciju metafilozofijâ, sadrži neprimjetnu, treću razinu u odnosu na oba koncepta metafilozofije, imanentistički i interno-eksternalistički. On dovodi u pitanje samu ideju metafilozofije i pritom, ne računajući korist od regeneracije filozofije kroz usložnjavanje refleksije i kulturu "konverzacije" (Rorty), ponavlja i stare greške filozofije, poput problema "trećeg čovjeka”.

Takav postav otvara potencijalno beskonačnu proliferaciju metameta-perspektiva unutar same filozofije. ${ }^{39}$ Najbolje je ilustrira Kantova kritika čistog uma, koja je provedena kao transcendentalna, tj. kategorijalna kritika metafizike, koja i sâma, već kod Aristotela, nije provedena neposredno naivno kao objektivistička teorija svijeta nego je višestruko refleksivno osigurana: autorefleksijom filozofije, kritikom drugih gledišta i metajezičnom kritikom filozofskog i običnog jezičnog pojmovnika. Na kraju će i Kantova kritika Aristotelovog "nekriticizma”, izrečena na kraju Kritike čistog uma, doživjeti historijsko-jezičnu metakritiku romantičara koja će i sâma biti zaboravljena da bi se jezična kritika filozofije, kao i sâma transcendentalna kritika, vratila u analitičkom pojmu metafilozofije s kojim smo ovdje počeli.

S druge pak strane, izvanfilozofske analize filozofije, kakve nalazimo u psihoanalizi, sociologiji, kulturnoj antropologiji, ukazuju na opću i principijelnu teškoću izvanfilozofskog pristupa koja se tiče filozofske relevancije takvih heterogenih metadiskursâ o filozofiji. Ona se čini

39 Za usporedivo stanje u psihoanalizi v. polemiku o pluralizmu i zajedničkoj teorijskoj osnovi u psihoanalizi Wallerstein 2005 i Green 2005. Usp. Boag 2016, 4: "[M] etapsychology now equates generally with 'theoretical perspective', so that each of the various psychodynamic schools have their own 'metapsychologies' (...) T[hus] psychoanalytic pluralism can be seen, in fact, as a pluralism of metapsychologies”. 
u obrnutom razmjeru s relevancijom filozofske refleksije o načelima mišljenja za posao samih znanosti u pitanjima metodologije. ${ }^{40}$ Jedna od posljedica tog nerazmjera je da autorefleksije i autoteoretizacije specijalnih znanosti uvijek na neki način i do određene mjere, hotimice ili nehotice, preko metarefleksije vlastite metode i opće metodologije, postaju sudionice metafilozofije, izložene riziku od "previše filozofije" i osuđene na "krivicu i kaznu" za "ponavljanje nužnih grešaka i uzaludnih ispravki”, kako će se izraziti Adorno. ${ }^{41}$

Taj se efekt dobro vidi upravo u psihoanalizi. S jedne strane, vidjeli smo ga na naprijed spomenutoj dvoznačnosti Freudove asocijacije metafizike kod uvođenja pojma metapsihologija, ali se dramatičnije pokazuje na njegovu odnosu prema filozofiji koji odaje iste elemente poricanja u psihoanalitičkom smislu pojma, kakve smo vidjeli kod Lazerowitza, oko uloge termina metapsihologija u tvorbi pojma metafilozofija. Freud je, naime, prikazivao odnos filozofije i psihoanalize uglavnom jednostrano kao interes i potrebu za psihoanalizom u psihologiji i drugim ne-psihološkim disciplinama (razvojnoj povijesti, povijesti umjetnosti, filozofiji, sociologiji, pedagogiji). ${ }^{42}$ Obrnuto, potrebu psihoanalize za filozofijom uglavnom je prikazivao samo kao zajedništvo motivâ između psihoanalize i filozofije, pri čemu filozofija u tome zajedništvu sudjeluje više u nesavršenim anticipacijama nego konceptualizacijama. To važi za Platona, Schopenhauera, Nietzschea, a napose kod epistemologa Eduarda von Hartmanna, čija je Filozofija nesvjesnog iz 1869. već po obećanju naslova trebala biti “od interesa”. No, Freud joj, kako je poznato, u prvom izdanju Tumačenja snova iz 1899/190o., posvećuje tek kritičku opasku kako "pesimistični filozof Hartmann ne razumije ulogu želje u teoriji snova i asocijacije ideja”. Međutim, u naknadnoj bilješci iz 1914., Freud priznaje — ali pritom koristi izvještaj trećeg autora — "istovjetno gledište u značajnoj točki”: naime da Hartmann ipak uviđa djelovanje "nesvjesnih motiva u umjetničkoj djelatnosti” i jasno izražava "zakon po kojem nesvjesni

40 Joll 2017.

41 Isti rizik izražava se na sukobu oko antirealizma i relativizma u Kuhnovoj teoriji o razvoju znanosti, v. monografski rad D. Francetića (ovdje).

42 Vidi S. Freud (1913), “Das Interesse an der Psychoanalyse”. Upravo taj izvanjski interes i potrebu Wittgenstein je, prema Lazerowitzu, odbio, da bi mu se vratio iznutra. O obrnutoj potrebi same psihoanalize za humanističkim znanostima, puno je manje riječ. Vidi Razinski 2016. 
ciljevi upravljaju asocijacijama naših misli”, ali ipak ostaje nesvjestan dosega takvog zakona kao načelnog i općeg djelovanja nesvjesnog. ${ }^{43}$

Nasuprot takvom eksternalizmu, drugo gledište o metafilozofiji je naprijed već spomenuti imanentizam kod Reschera i Williamsona koji inzistiraju da se termin metafilozofija u potpunosti odbaci i zamijeni terminom filozofija filozofije, odbijajući svaku perspektivu koja bi objektivirala filozofska pitanja s bilo kakvog nezavisnog stanovišta izvan filozofije, ali također i unutar same filozofije, takoreći nadfilozofije odozgô. No, takvo novije gledište, koliko god simpatično i privlačno filozofima i filozofkinjama izvan analitičke tradicije, ne predstavlja više nego povratak načinu na koji su različiti filozofi i filozofkinje iz različitih škola i u različitim vremenima, implicitno ili eksplicitno, oduvijek koncipirali odnos između filozofske refleksije o predmetima i samorefleksije filozofije, i to najkasnije od Platona i Aristotela preko Kanta, Hegela i drugih idealista do metafilozofskih refleksija kod Heideggera, Adorna, Lefèbvrea ili Hanne Arendt. ${ }^{44}$ No, premda vidimo da je takvo filozofsko shvaćanje metafilozofije navelo i postanalitičku tradiciju da napusti interni eksternalizam lingvističko-logičke analize odozgô i popise prividnih problema filozofije, metafilozofiju i dalje prati neriješeni latentni problem imanentizma prateće svijesti, samo-svijesti ili "su-svijesti". ${ }^{45}$ Može li se nutarnja metasvijest filozofije o sebi razumjeti naprosto samo kao izdanak ili instanca prirodne sposobnosti mišljenja za autorefleksiju, koja u filozofiji inherentno, takoreći autogeno, proizvodi refleksiju o sebi kao što generira refleksiju "o bilo čemu drugome" (Williamson)?

Naime, na pretpostavci da metafilozofska refleksija proizlazi spontano i automatski, ili po analogiji, iz posebnog predmetnog mišljenja teško možemo objasniti genezu, a još manje prirodu, metafilozofskog

43 Vidi Freud 1900, Die Traumdeutung 151 i 506, bilj. Za sistematičan pregled Freudovog odnosa prema filozofiji i filozofima v. Paul-Laurent Assoun 1976. u kojem nema ni spomena o Hartmannu. Spomenut će ga tek u kasnijoj monografiji (Assoun 2013, 15) kao primjerak "jedne metafizike, tisuću milja udaljene od metapsihologije”.

44 Vidi metafilozofski portret $\mathrm{H}$. Arendt, koji njezinu političko-teorijskom profilu suprotstavlja filozofski, židovski i ženski identitet, u M. Betz Hull 2002, The Hidden Philosophy of Hannah Arendt, osob. 4. The Arendtian person, 123-170.

45 Vidi osobit naglasak na "conscientious endevour" u Rescher 2007, 53. Isti moment sadrži, kako ću još pokazati, izraz syneídein, syneídesis naspram epistếmē kod Sokrata (Platona). 
mišljenja. Na toj osnovi ono se ne čini ništa objašnjivije od nastajanja samosvijesti iz objektalne, predmetne svijesti. Ako je objektalna svijest refleksivna, je li samosvijest refleksija refleksije, to jest, refleksija iste vrste, samo drugog stupnja? ${ }^{46}$ Otud se čini razumljivim da novi imanentisti u metafilozofiji poput Reschera, pritisnuti dužnošću analitičkog objašnjavanja, radije posežu za pretpostavkom inherentne refleksivnosti filozofije i prešutnom analogijom između metafilozofije s prirodnom metarefleksijom umjesto da se upuste u produbljeniju i složeniju filozofsku analizu opravdanosti takvog autogenog (zapravo “parthenogenog”) shvaćanja metafilozofije. Pretpostavka da filozofirati već po sebi, in actu, znači misliti metafilozofski, ne čini se da dostatno objašnjava nastanak metafilozofije iz filozofije kao što ni teorija predmetne svijesti ne objašnjava nastanak samosvijesti ili pak lingvistika nastanak metajezika iz objektnog jezika. Prije bi se moralo priznati da smo zbog tog strukturalno-genetičkog pitanja i dalje osuđeni na analogije između metafilozofije i prirodne refleksije nego što možemo objasniti nastanak obiju. Kao što filozofska teorija uma koristi jedan (refleksivni) model svijesti za objašnjenje samosvijesti, ili lingvistika operira terminom metajezična funkcija jezika da bi opisala jedan dio jezičnog fenomena, tako na kraju i filozofija operira terminom metafilozofija za identifikaciju jednog unutarfilozofskog sloja mišljenja (logičkog ili epistemološkog) koji će proglasiti posebnim tipom mišljenja i normativnom konceptom filozofije uopće.

Time se u vertikalnoj perspektivi i znatno dramatičnije nego kroz horizontalno raspršeni repertoar metafilozofskih i metodoloških pitanja potvrđuje pretpostavka da je metafilozofija kvantitativno i kvalitativno koekstenzivna sa samom filozofijom, i da prijedlog 'meta' u funkciji prefiksa, kojim pokušava prekoračiti polje svoje unutrašnje, objektne refleksije, može ili beskonačno umnožavati ili ga otpisati kao jezično zališan. To se polje uvijek samoproširuje kroz refleksivni rad filozofije čiji se stupnjevi mogu, ali ne moraju, uvijek iznova imenovati umnožavanjem prefiksa meta-meta. Sukladno tome, ako metafilozofiju ne shvatimo kao drugo ime za epistemologiju određene filozofije u primjeni na samu sebe, ne preostaje joj drugo nego da, bez toga posljednjeg utočišta u samoznanju, bude beskoristan organ u tijelu filozofije, poput slijepog crijeva, koji zapravo samo smeta svojom prisutnošću.

46 Za teorije samosvijesti u modernoj i suvremenoj evropskoj i u analitičkoj filozofiji v. pregled i diskusiju u Frank (Hg.) 1991 i 1994. 
Takav neveseli rezultat učinak je, po mome mišljenju, dvostruke, uglavnom netematske redukcije u samoj osnovi metakritike filozofije: jednom, već spomenute zamjene analitičke filozofije jezika analitičkom epistemologijom, koji zakriva obrat "internog eksternalizma" odozgô (zakonitost ispravnog jezika) u sličan nutarnji eksternalizam odozdô (u zakonitost pouzdane spoznaje); drugi put, prethodno već provedenom redukcijom starijih jezično-filozofskih refleksija na analitičku filozofiju jezika 20. stoljeća, o čemu će kasnije biti riječi detaljnije. Rezultat je taj da se metafilozofija u današnjoj postanalitičkoj tradiciji pretežno shvaća i prakticira kao uvod u preskriptivni i normativni analitičko-epistemološki model metafilozofije. ${ }^{47}$ Ona je u izričitoj suprotnosti prema deskriptivnom ili historijskom pojmu metafilozofije koji navodno nije dio filozofije, poput same povijesti filozofije. Štoviše, najnoviji trend ide ka tome da se pod imenom 'metafilozofija' inaugurira samostalna filozofska poddisciplina, paralelna s ontologijom, logikom, epistemologijom, lingvističkom filozofijom, etikom, estetikom itd., u čistom obliku ili u različitim primjenama. ${ }^{48}$ No, takav koncept, da bi objektivirao sâmu filozofiju, izvodi metafilozofiju iznutra bilo iz općeg refleksivnog karaktera samog filozofskog mišljenja ili pak uzima jednu od disciplinâ filozofije umjesto druge (logiku, filozofiju jezika, metaepistemologiju sve do metaetike), i počiva, čini se, na još jednoj netemetiziranoj redukciji. Ovaj put na redukciji pojma metajezik.

Naime, iz povijesti rane analitičke filozofije znamo da se jezična analiza odnosi na filozofsko istraživanje istine i formalnog jezika, za što je u filozofiji skovan i termin metajezik, prvi put kod Alfreda Tarskog. Premda sâm Tarski eksplicitno povezuje svoj projekt s Aristotelom i time barem historijski proširuje okvir jezične analize u filozofiji, prvom žrtvom takve metafilozofske kritike u filozofiji postali su upravo prirodni jezik i sva filozofija koja se temelji na njemu. Takva povijest

47 Usp. karakteristično dvoznačan stav u Williamson 2007, ix: “The primary task of the philosophy of science is to understand science, not to give scientists advice. Likewise, the primary task of the philosophy of philosophy is to understand philosophy, not to give philosophers advice - although I have not rigorously abstained from the latter." Za izravnije preskriptivan pristup v. Williamson 2018; također Rescher 2014 i Rescher 2010.

48 Søren Overgaard, P. Gilbert, S. Burwood 2013, 11. Vidi nove artikulacije kontekstualne metafilozofije (Gakis 2012), naturalizirane (zapravo, socijalne) metafilozofije (Morrow i Sula 2011). 
specijalnog pojma metajezik u suvremenoj analitičkoj filozofiji zakriva adekvatniju, ali, prema mome znanju, neosviještenu pozadinsku analogiju između imanentističkog razumijevanja metafilozofije sa shvaćanjem općeg pojma metajezik u lingvistici, u smislu sposobnosti prirodnog jezika da reprezentira i opisuje sâmoga sebe. ${ }^{49} \mathrm{Na}$ toj osnovi, drugačijoj od logike i istraživanja formalnog jezika, možemo uzeti, po analogiji, da bi metafilozofija bila instanca opće "metajezične funkcije" na posebnom slučaju filozofije kao tipa mišljenja s apstraktnim, ali još uvijek prirodnim jezikom, koja, poput prirodnog jezika, reprezentira, objektivira i opisuje sebe kroz autorefleksiju, razvijajući pritom poseban metajezik. ${ }^{50}$ Međutim, usprkos razumljivosti i intuitivnoj prihvatljivosti ove analogije, takav argument o metajeziku nije, prema mome uvidu, našao širu teorijsku primjenu. Kod nekih autora može se prepoznati samo implicitno, bez tematizacije, u ponavljanju uvjerenja da filozofsko mišljenje kao takvo, po sebi, predstavlja viši tip prirodnog mišljenja ili inteligencije gdje se najbolje, ako igdje, ostvaruje sposobnost mišljenja za samosvjesni opis. ${ }^{51}$

No, premda se to čini boljim rješenjem za imanentističko razumijevanje metafilozofije od posebnog (formalnog) jezika logike, ostaje ipak, kao nužni kolateralni učinak metajezika, samoobjektivacija u samom meta-aktu koja, takoreći iznutra, subvertira totalni imanentizam meta-akta u eksterni moment na jezičnom ili misaonom aktu prvog reda i čini njegov imanentni karakter "nekako metafizičkim”. Kad ne

49 Vidi novije socijalno-lingvističke diskusije o metajeziku u Jaworski et al. 2004, 3: "The starting point for all studies of metalanguage is the familiar observation that language is a unique communicative system in that it can be used to describe and represent itself. This idea opens up a perspective on a general set of processes that define 'the metalinguistic function of language."

50 U tom kontekstu na važenju dobiva okolnosti da indijska tradicija poznaje lingvistički koncept metajezika koji potječe iz jezičnih refleksija u gramatičkoj i logičkoj literaturi, ali se ne odnosi na pitanja istine i formalnog jezika nego na prirodni jezik. Vidi opsežnu raspravu o konceptu metajezika u indijskoj tradiciji u Staal 1975; o ulozi Tarskog, osob. 315-316. O pojmu metafilozofije i ulozi metajezičnih refleksija u klasičnoj indijskoj filozofiji na primjeru nyāye v. prilog G. Kardaša (ovdje).

51 Takvu ideju refleksivnosti mišljenja slijedi, po mome mišljenju, Rescher 2014, 53, iako je ne razvija nego samo pretpostavlja: "Philosophizing is an inherently reflective discipline. Here, if anywhere, we have to be concerned about what we are doing in the conscientious endeavor to provide a cogent rationale for doing it our way." (Kurziv moj.) 
bi bilo te subverzije, ostaje pitanje možemo li kroz analogiju između metafilozofije s općim pojmom prirodnog metajezika objasniti posebni status metafilozofije, do kojeg je osobito stalo baš imanentistima, i u čemu bi se ona uopće sastojala? Naime, premda metajezik u lingvistici ne imenuje samo funkciju ili moć prirodnog jezika da se odnosi na sebe, nego i ontološki sloj jezika unutar prirodnog jezika koji nazivamo metajezikom (poput gramatičke terminologije), on nosi sobom i dodatnu sistematsko-teorijsku prednost da objašnjava i sâmu lingvistiku kao samo jedan od diskursâ o jeziku: diskursi nastaju i opstoje zahvaljujući upravo toj funkciji koja se odnosi na jezični kôd i preklapa s tzv. poetskom funkcijom, koja se odnosi na poruku; obje pripadaju koliko znanosti toliko i govornoj i poetskoj praksi. ${ }^{52}$

No, pitanje je i dalje što ta analogija s metajezičnom sposobnošću prirodnog jezika donosi za imanentističko razumijevanje metafilozofije? Možemo li i metafilozofiju shvatiti, po analogiji, kao neku vrstu metajezičnog autorefleksivnog diskursa samog mišljenja o sebi? Trebamo li sad uzeti lingvistiku umjesto logike da nam dade značenje pojma metafilozofija, kako to pokazuje koncept metalingvistike nastao u analitičkoj tradiciji filozofije jezika? Hoćemo li se tako konačno prestati brinuti za metafilozofiju, budući da je ionako uračunata u samu prirodnu moć jezika da razvije diskurs o sebi, samo ako ga primijenimo na uže polje filozofije? Ili je riječ o sposobnosti prirodnog mišljenja da se odnosi na sâmo sebe, tako da konačno možemo govoriti o metafilozofiji kao metamišljenju, bez potrebe za uvođenjem teme metajezik? Ili metafilozofiju trebamo shvatiti dosljednije kao izraz poetske funkcije jezika bez rizika da napustimo mišljenje i padnemo u mistiku pjesnikovanja kasnog Heideggera?

Na sreću, pitanja odnosa između jezika i mišljenja daleko su od jednostavnosti, što se očituju već u proliferaciji pojmova, sve odreda neologizama skovanih analogno editorskom pojmu metafizike, koji čine kategorijalni aparat i metodološki pojmovnik disciplina pod zajed-

52 Vidi Jakobson 1985 (1956), 121: "We realize ever more clearly that any verbal message in the selection and combination of its constituents involves a recourse to the given code and that a set of latent metalingual operations underlies this perpetual framework" (121). "Any attempt to reduce the sphere of poetic function to poetry or to confine poetry to poetic function would be a delusive oversimplification. Poetic function is not the sole function of verbal art but only its dominant, determining function, whereas in other verbal activities it acts as a subsidiary, accessory constituent" (115-116). 
ničkim krovom društvenih i humanističkih znanosti. Svi oni danas predstavljaju instrumentarij metafilozofije iz kojeg se crpi "meskalin filozofske elite" (Lazerowitz), umjesto običnog opijuma za filozofski narod, kakav poznajemo još od "ljekovitog lišća" iz Platonova Harmida i drugih dijaloga za liječenje neznanja: epistemologije, logike, filozofije jezika i medija, estetike ili, danas masovno popularne bioetike i filozofije ekologije. Ipak, kako u tu "Platonovu farmaciju" (Derrida) pripada svakako i kukuta, lijek koji okončava životnu bolest pod imenom filozofije, slijedit ćemo trag poetske funkcije jezika u metafilozofiji. Ona nije samo ta koja pokreće metagovore i njihovo beskonačno umnožavanje nego unosi razliku u moduse njihove samoobjektivacije.

\section{Avatari antifilozofije}

Za olabavljenje, ako ne i razvezivanje čvora imanencije, čini se korisnim baciti pogled na malo širi idejno-povijesni okvir, makar samo u kratkom ekskursu. Metafilozofija se, osobito u imanentističkom smislu bavljenja filozofije "samom sobom", u suvremenim prikazima obično dijeli na eksplicitnu ili tematsku, koja navodno pripada analitičkoj tradiciji 2o. stoljeća, nasuprot implicitnoj ili spontanoj metafilozofiji ranije "kontinentalne" tradicije. .3 Međutim, pravo stanje stvari posve je daleko od jednostavnosti takve podjele.

Metafilozofija je prisutna u jakom smislu pojmovno i eksplicitno, premda ne nužno i terminološki, kroz cijelu povijest razumijevanja filozofije, zajedno s jezično-kritičkom refleksijom o jeziku. O tome ne svjedoče, kako ću još bliže pokazati, samo filozofske autorefleksije općeg karaktera kod klasičnih autora, poput Platona ili Aristotela; naprotiv, ona se vidi već u arhajskim oblicima samo-razlikovanja filozofije naspram drugih oblika mišljenja i života, poput religije, teologije, politike, historije i kozmologije, ali i svakodnevnih fenomena života, poput čuđenja. ${ }^{54}$ Takva eksplicitna kritička auto-razmatranja toliko obilježavaju nastanak filozofije u ranom razdoblju grčke filozofije kod Heraklita i Ksenofana, potom Elejaca i Anaksagore, te osobito

53 Podjelu potcrtava Joll 2017; v. Overgaard, Gilbert, Burwood 2013, 10-11. Rescher 2014, xi ističe razliku između "self-detached perspective" moderne metafilozofije i ograničenosti stare metafilozofije na "own philosophical business".

54 Vidi osvrt na sociološke, kulturno-historijske, psihološke i feminističke perspektive metarefleksije u filozofiji, znanostima i umjetnosti, napose afirmaciju globalne historije filozofije, u Čačinovič (ovdje). 
kod sofista i Sokrata, da ih nije potrebno posebno dokumentirati. Međutim, to ne važi samo za grčko-evropsku tradiciju nego jednako tako, ako ne i više, i za indijsku filozofiju koja se već u počecima, i ranoj vedanti i ranom kriticizmu đaina i buddhista, naglašeno uspostavlja kao više i posebno metaznanje ili znanje-drugog-reda nasuprot religijsko-ritualnoj koncepciji apsoluta i pridruženim sistematskim oblicima konkretnih znanja poput gramatike, fonetike, geometrije ili astronomije. ${ }^{55} \mathrm{U}$ međuvremenu je opće mjesto komparativnog filozofskog obrazovanja da takva metadimenzija čini matricu racionalnosti u indijskim klasičnim filozofijama, ali također i u klasičnim epovima i ekonomsko-političkim traktatima, gdje tvori mrežu međusobnih referenci, kritikâ i autokritike, između i unutar pojedinih škola, a također između racionalistâ (haituka) i objavne misli. ${ }^{56}$

Štoviše, proces refleksivno-kritičke diferencijacije tipova mišljenja ne djeluje samo prema vani, nego također i unutar korpusa same filozofije, kako u pogledu predmeta tako i u pogledu metode i stila, predmetnih područja i škola, sve do sljedbi ili životnih zajednica i učiteljstva. ${ }^{57}$ Štoviše, taj proces vanjske i unutrašnje diferencijacije djeluje, od samih početaka, povratno i na sâmu filozofiju kroz autokritičke tendencije ka ukidanju apstraktne teoretičnosti mišljenja koja sama po sebi ne doprinosi etičkoj vrijednosti istine, cilju spasenja i slobode. ${ }^{58}$ Taj trend poznajemo, dakako s različitim ulozima i ishodima, već od rane upanišadske kulture osamljeništva i Buddhine kritike filozofije te, s druge strane, od sofistike i Sokrata, a ne tek od post-hegelovskih mislilaca 19. stoljeća, poput Marxa, Kierkegaarda i Nietzschea, ili njihovih nastavljača na desnom i lijevom političkom krilu filozofije

55 Za metarefleksiju o znanju u ranoj vedanti v. klasično mjesto S. Radhakrishnan 1953, 95-103. Za klasičnu indijsku (vedantsku i kasnobuddhističku) refleksiju o metafilozofiji v. G. Kardaš (ovdje).

56 Vidi Ganeri 2001 (osob. dio I.1 Early recognition of a 'practice of reason', 7-10). Za negativno vrednovanje "racionalista" i kritičke analize (ānvīkšikī) u epskoj književnosti v. Kardaša (ovdje).

57 Vidi Hadot 1995, Philosophy as a Way of Life; također Wharton (2010), "The Teacher as Mother or Midwife?"

58 Za izraženost figure "liječenja duše" filozofijom i u zapadnoj i indijskoj tradiciji od Wittgensteina, W. Jamesa i Nietzschea unatrag do Spinoze, Tome Akvinskog i Platona te Rāmānuđe i Patāñđalija v. radove u Carlisle i Ganeri ed. 2010. Za terapijsku funkciju učenja o praznini (śūnyavāda) kod kasno-buddhističkog dijalektičara Nāgārđune v. Kardaš (ovdje). 
20. stoljeća, od Heideggera do Gadamera i Derride, ili Adorna i rane kritičke teorije do Habermasa i drugih.

Očigledno je, dakle, da teškoće oko pojma metafilozofije sežu dublje i šire od rješenja kakvo nudi nedefinirani imanentizam pojma u suvremenoj analitičkoj diskusiji i kakav nam obećaje fraza filozofija filozofije. Zato, konfiguracije imanentističkog argumenta u analitičkoj tradiciji možemo, čini se, bolje vidjeti na drugoj strani filozofije i naizgled posve drugačije, u suvremenim filozofijama evropske poststrukturalističke, hermeneutičke, marksističke i feminističke tradicije od 1960-ih naovamo. U njoj se sâm pojam filozofije čini tako nepovratno rastočen negacijama "totaliteta" i "samoimanencije" filozofije kroz različite artikulacije "mišljenja same stvari mišljenja”, od bitka, prakse, revolucije ili pak postmoderne, slabe i nomadske mîsli, da se takvo stanje ogleda i na samoj metafilozofiji. ${ }^{59}$ Ona je gotovo u potpunosti nestala na nominalnoj razini, a pitanja o filozofiji kruže pod negativnim terminima anti-, post- i trans-filozofija. S obzirom na tako široko razapet lûk refleksije u idejnopovijesnom i konceptualnom vidu, od metafilozofije, preko transfilozofije do antifilozofije, danas se ponovno izdanje knjige humanističkog marksista Henrija Lefèbvrea pod jednostavnim naslovom Metafilozofija iz 1965., prešućene u svoje vrijeme i gotovo posve zaboravljene, čini kao pravi kuriozum. ${ }^{60}$ Knjiga koja slijedi imanentističko shvaćanje moderne filozofije, otvoreno iskazujujući svoju odanost autorstvu i produkciji kod Hegela, Marxa i Nietzschea, vjerojatno je upravo zbog duga prvoj dvojici nestala sa scene 6o-ih pod nanosima althusserovskog antihumanizma i postmodernizma da bi tek danas služila liječenju filozofije od "bolesti" postmoderne pod imenom antifilozofije. ${ }^{61}$

59 Vidi noviju diskusiju o ambivalenciji u Hegelovu navodnom konzervativizmu "kraja filozofije" u Filozofiji prava nasuprot progresivnosti njezine povijesne uloge u Filozofiji povijesti, Povijesti filozofije i Fenomenologiji duha u Ware 1996. Za metafilozofiju kritičke teorije i filozofije prakse v. Bronner 2011.

60 H. Lefèbvre, Métaphilosophie, prvo izdanje 1965 (Paris, Minuit); novo fr. izdanje, Ed. Syllepse, 20oo; engl. prijevod Verso 2016, pr. D. Fernbach, priredio S. Elden s opsežnim reaktualizirajućim uvodom; pogovor G. Labica, "Marxism and Poetry".

61 Vidi G. Labica, 2016. Za bliži prikaz humanističke motivacije metafilozofije kod Lefèbvrea, ali i kasnu recepciju knjige kod nas, na zalasku jugoslavenske praxis filozofije $1980-$ ih i predominaciju postmoderne, i danas, v. pobliže u Veljak (ovdje). 
Pritom, prevlast antifilozofije čini se tako dubokom i dalekosežnom da čak i ponovni apeli za reafirmacijom filozofije u klasičnom smislu protiv postmoderne subverzije, poput dvaju "manifestâ za filozofiju" Alaina Badioua, proglašavaju antifilozofiju nužnim uvjetom same filozofije.

"Antifilozofija je uvijek ono što, na samim svojim krajnostima, postavlja novu zadaću filozofije ili svoju novu mogućnost u figuri nove zadaće. Mislim na Nietzscheovo ludilo, Wittgensteinov čudni labirint, Lacanovu konačnu zamuklost. U svim tim slučajevima antifilozofija uzima oblik jedne ostavštine. Ona nešto što je iznad nje same zaviješta onome protiv čega se bori. Filozofija je uvijek baštinica antifilozofije." ${ }^{2}$

Badiouova formulacija, koja sumira tendencije transfilozofskih projekata 19. i 20. stoljeća od Nietzschea preko Wittgensteina do Lacana, evocira ponovo, ali u još dramatičnijem obliku, ono "invarijantno svojstvo" filozofskih iskaza koje proizlazi iz neke neodređene prirode, "nečeg iznad sebe" što ih usmjerava, i "zaviješta ga upravo onome protiv čega se bori”, tj. filozofiji, bilo starijoj metafizičkoj teoriji spoznaje, bilo prema njezinoj kritici koja želi utemeljiti novu metafiziku. Da to važi čak i po cijenu autodestruktivnosti, pokazuje linija analitičke filozofije od kasnog Wittgensteina do potpune razgradnje epistemoloških temeljâ filozofije, u knjizi Richarda Rortyja Filozofija i ogledalo prirode [Philosophy and the Mirror of Nature] iz 1979., koja zagovara radikalno konstruktivistički, "konverzacijski" koncept filozofije, oslobođen od idolatrije istine i utemeljenja. Jednu suvremenu verziju takve platforme možemo danas vidjeti u shvaćanju antifilozofije u analogiji s antiumjetnošću readymade-a. ${ }^{63}$ No, upravo antifilozofija, koja će od

62 Usp. Alain Badiou 2001, "Who is Nietzsche?", 10: "Antiphilosophy is always what, at its very extremes, states the new duty of philosophy, or its new possibility in the figure of a new duty. I think of Nietzsche's madness, of Wittgenstein's strange labyrinth, of Lacan's final muteness. In all three cases antiphilosophy takes the form of a legacy. It bequeaths something beyond itself to the very thing that it is fighting against. Philosophy is always the heir to antiphilosophy.” Vidi opsežan prikaz Badiouove anti-antifilozofske koncepcije metafilozofije naspram Nietzschea, Wittgensteina i Lacana u B. Bosteels 2008 i 2011.

63 Vidi B. Groys 2012: “(...) antiphilosophy, a readymade philosophy that ascribes universal philosophical value to certain already-existing ordinary practices, in the same way in which practices of the artistic 
tada sve radikalnije potiskivati istinosni diskurs filozofije o svijetu i o samoj sebi te uvoditi nove, postmetafizičke, post-veridičke procese konverzacije i njihove rječnike, prožeta je filozofskim utjecajima koji su prethodno rastočili granice podjele na analitičku i kontinentalnu filozofiju s hermeneutičkog i kritičko-teorijskog krila evropske filozofije 20. stoljeća. Tamo Adornova kritika teorije spoznaje iz 1956. pod imenom metakritike, izdana deset godina prije Lefèbreove knjige, predstavlja bez sumnje prvu metafilozofsku intervenciju koja se, rečeno s Badiouom, "zaviješta onome protiv čega se bori". ${ }^{64}$

Adorno je Metakritiku teorije spoznaje, nastalu iz tipično akademskih, egzegetskih studija o Husserlu ranih 30-ih godina u izbjeglištvu u Oxfordu, čitavo desetljeće kasnije sâm nazvao "najbližom" svome glavnom filozofskom djelu, Negativna dijalektika iz $1966 .{ }^{65} \mathrm{No}$, u Metakritici se izraz metakritika spominje samo jednom u tekstu, i to tako da evocira istu invarijantnu prirođenu manu filozofije kakvu smo već sreli u analitičkoj tradiciji. Ali "nelječiva bolest” koju je dijagnosticirao Lazerowitz, ne odnosi se kod Adorna više na objekt terapije, tj. na filozofiji, kao kod Lazerowitza i ranije Wittgensteina. Ona sad zahvaća samu terapiju. Govoreći o aporijama "perenirajuće teorije spoznaje", Adorno piše karakteristično zakučastim stilom:

\section{“(...) svaka stoji pod kletvom Anaksimandra čija je filozofije bît-}

readymade ascribe artistic value to ordinary objects." (ix) "A traditional philosopher is like a traditional artist: an artisan producing texts. An antiphilosopher is like a contemporary art curator: he contextualizes objects and texts instead of producing them (...) Antiphilosophy does not abolish philosophical metanoia, but rather democratizes it. Evidence becomes an effect not of production but of post-production.” (xiii).

64 Da sličnu ambivalenciju sadrži i Kuhnov stav naspram antirealističkih konzekvencija svoje konceptulno-relativističke interpretacije znanosti v. prilog D. Francetića (ovdje), koji zauzima konceptualno-relativističko stanovište. Za anti-relativističku interpretaciju na pretpostavkama Peirceovog pragmatizma v. noviju opsežnu monografiju o metafilozofskim aspektima Kuhnove koncepcije znanosti u B. Mladenović 2017, Kuhn's Legacy. Epistemology, Metaphilosophy, and Pragmatism (osob. pogl, 4, 6); o jezično-filozofskoj podlozi Kuhnove teorije znanstvene revolucije v. Gattei 2008, Thomas Kuhn's “Linguistic Turn” (osob. pogl. 4).

65 U svome prilogu N. Čačinovič smatra radikalno metafilozofskom knjigom Dijalektiku prosvjetiteljstva i smiješta se u tradiciju kritičke teorije koja "samu sebe smatra uvijek već dijelom problema, ne nastoji postići odmak i kontemplaciju, nego odrediti implikacije vlastite pozicije" (v. ovdje 124). 
ka, jedna od najranijih, takoreći prorekla kasniju sudbinu svih. Metakritika teorije spoznaje iziskuje konstruirajuću refleksiju svojih svezâ kao svezâ krivnje i kazne, nužnih grešaka i uzaludnih ispravki”. ${ }^{66}$

Metakritika koja se tiče teorije spoznaje i takoreći evocira zaokret analitičke metafilozofije od filozofije jezika ka kritičkoj epistemologiji, izriče nešto posve suprotno objema ranije navedenim verzijama metafilozofije, imanentističkom i internalističko-eksternalističkom. Ako nešto predstavlja "bolest" u samoj srži filozofskih iskazâ koja uzrokuje "odsutnost slaganja" (Lazerowitz) i onemogućuje izlučivanje metafilozofije iz filozofije (Rescher), isto je ono što nas osuđuje na nužne greške i uzaludne ispravke u rekonstrukciji svojih kontekstâ i zaviješta filozofiji ono isto protiv čega se bori (Badiou). To nije nesvodiva različitost stavova o objektima nego ono od čega uzalud i pogrešno očekujemo da proizvede jedinstvo: sâm metamisaoni karakter filozofskog mišljenja, njegova moć da se odnosi na samo sebe i proizvodi svoj vlastiti metaidiom. Logička analiza jezika, koja se prva predstavljala kao privilegirano umno mjesto odakle metafilozofija terapira tijelo filozofije, i sâma je, proizvodeći jedan pojam metafilozofije, instanca osporavanja koje navodno liječi, bolest $u$ samoj terapiji. O tome govori "anaksimadrovska kletva" svih teorija spoznaje, uključujući i Adornovu "konstruirajuću metarefleksiju njezinih uvjeta". Ona naime i sama svoju konceptualnu motivaciju i porijeklo u historijskom pojmu metakritike prikazuje samo mimetički u naslovu dok skriva njezino jezično-filozofsko porijeklo. Osim što se u Adornovoj Metakritici jedva jednom spominje termin metakritika, nigdje i nijednom se ne javlja ime njezinog autora kojeg Adorno naslijeduje.

Pred tako praznom scenom nad kojom kod Adorna stoji literarno-filozofski i kulturno-povijesno jednoznačno obilježen natpis "metakritika" neizbježno je pitati se - kakva je to igra aluzijama kojom se Adorno bez sumnje svjesno upisuje ne samo u povijest filozofske refleksije

66 Prijevod moj. Usp. Adorno 1956, 32: "eine jegliche steht unter dem Fluch des Anaximander, dessen Seinsphilosophie, eine der frühesten, gleichsam das spätere Schicksal aller weissagte. Metakritik der Erkenntnistheorie erheischt die konstruierende Reflexion ihres Zusammenhangs als eines von Schuld und Strafe, von notwendigem Fehler und vergeblicher Korrektur”. To je gotovo sve što Adorno kaže o metakritici. Vidjet ćemo da njezin odredbeni moment "istraživanje svojih svezâ” već kod Aristotela pripada u definiciju same filozofije. 
o teorijama spoznaje nego u tradiciju pod imenom 'metakritike' koja je koliko filozofska toliko literarna i jezično-povijesna da obuhvaća najslavnije glave od Kanta do Nietzschea, a nužno upućuje na izvor metakritike teorije spoznaje, najprije na Hamanna i Herdera.

\section{Metakritika ili "genealogija uma" (Hamann i Herder)}

Pod imenom metakritika stanovište metafilozofije prvi put je formulirao Johann Georg Hamann, jedan od najosebujnijih i dugo u filozofiji gotovo posve zaboravljen lik poetskog mislioca iz tzv. Herderova kruga. Njegov mali, ali epohalni spis od svega desetak stranica, pod karakterističnim naslovom "Metakritika o transcendentalnom purizmu uma" [Metakritik über den Purismum der Vernunft] iz 1784., predstavlja kritiku same ideje o "čistoći” uma i jezični spomenik filozofske literature, a postao je općenito poznat tek u posthumno izdanim Hamannovim spisima [Hamann's Schriften] iz 1825. Opsežno ih je recenzirao Hegel 1828., kratko prije svoje smrti, izražavajući pritom svoja pomiješana osjećanja: privrženost konceptualnom sadržaju, divljenje teorijskoj genijalnosti i kritiku na račun manjka dosljedne sistematske razrade ideja. ${ }^{67}$ No, sâm izraz metakritika pojavljuje se u Hamannovu spisu čak manje nego kod Adorna - nijednom (osim u naslovu). ${ }^{68}$

Hamannov maleni tekst predstavlja editorsku kontroverzu. Za dugo vremena bio je poznat u užem krugu romantičara kroz prijepise pisma Herderu od 15. rujna 1784., koje je sadržavalo nacrt kritike same ideje čistog uma nakon prvog izdanja Kantove Kritike čistog uma (1781) i tri godine kasnije elaboracije u Prolegomenama za svaku buduću metafiziku iz 1783. Hamannov tekst prethodi petnaest godina Herderovu spisu Eine Metakritik zur Kritik der reinen Vernunft [Metakritika o Kritici čistog uma], objavljenom 1799., jedanaest godina nakon Hamannove smrti (1788), u kojemu Herder na nekoliko stotina stranica u dva sveska detaljno prikazuje sve sistematske dijelove Kantove Kritike, tada već

67 Vidi Hegel 1828 (1986), “Hamanns Schriften”, 275-352. Za Hegelov ambivalentni odnos prema "neprovarljivosti i nerazumljivosti" koja iziskuje "deblje komentare od samog djela”, v. i Bayer 2012 (1988), osob. 29-30; Wohlfahrt 1984, "Hamanns Kantkritik", 401. Međutim Wohlfahrt, koji se višekratno referira na Hegelovu recenziju, naglašava utjecaj Hamanna na formaciju Hegelove spekulativne logike i filozofije uopće.

68 Za blisku strategiju meta-imenovanja kod Kierkegaarda, kod kojeg se “udvostručena riječ 'kriza' iz naslova nigdje ne pojavljuje u samome tekstu”, dok je čitalac "pozvan da je domisli, uspostavi i sam udvostruči njezinu referenciju”, v. prilog Lade Čale Feldman (ovdje, 258). 
u drugom izdanju. ${ }^{69}$ No, Hamannovo pregnantno djelce postalo je legendom i stvorilo literarnu modu ili žanr, poput tzv. "sokratičkih dijaloga”, i prije nego što je prvi put tiskano 180o., također posthumno, u zbirci radova raznih autora pod naslovom Mancherley zur Geschichte der metakritischen Invasion [Ponešto za povijest metakritičke invazije]. Taj dokument metakritičke konjunkture očito je bio tako razgrabljen da se izdavač sabranih Hamannovih spisa iz 1825. morao osloniti samo na Hamannovu rukopisnu ostavštinu bez uvida u prvotisak. ${ }^{70}$

$\mathrm{Na}$ temelju eklatantne razlike u opsegu radova i stupnju razrađenosti sadržaja, te nekih biografskih elemenata kronološke naravi, mnogi istraživači ne pripisuju Herderu samo izvorno autorstvo za ideju metakritike nego čak posve prešućuju Hamanna. ${ }^{71}$ Usprkos tome ipak važi kao osigurano da je Hamannov neologizam 'metakritika' već od pisma Herderu 1784. do prve tiskane publikacije spisa 180o. postao takoreći zaštitno ime svih post-kantovskih kritika transcendentalne filozofije. ${ }^{72}$ Herder je preuzeo termin odatle, što mu je priskrbilo čak i optužbu za plagijat. ${ }^{73}$ No, premda Hamannov spis iz 1784., u uspored-

69 Herder 1799 (reprint 1967). Riječ je opsežnom spisu u dvije podcjeline s naslovima "Verstand und Erfahrung" (Erster Theil) i "Vernunft und Sprache"(Zweiter Theil). Herder se u uvodu prvom dijelu referira izričito na 2. izdanje Kritike čistog uma i na Prolegomena (v. detaljniju diskusiju ovdje u nastavku).

70 Hamann's Schriften. Siebenter Theil, herausgegeben von Friedrich Roth, Leipzig: G. Reimer, 1825 , str. vi. (Na ovo ću se izdanje referirati u nastavku rada.)

71 Griswold 1988, 145 (bilj. 2), bez spominjanja Hamanna, pripisuje metakritiku Herderu pozivajući se na L. Becka 1978, 25, a ovaj bez daljnjih pitanja na Seebohma 1972, koji Hamannov spis kvalificira kao "radni papir", zajednički s Herderom, "jedne stvarne, a ne formalne jezične kritike čistog uma” (isto, 59, bilj. 3).

72 Vidi Beiser 1987, 37-43. Također Bayer 2013, 66: “'Metakritika' je pojmovno-povijesni novum, koji se prvi put spominje u Hamannovu pismu Herderu od 7. srpnja 1782. i označava naslov planiranog spisa."

73 Seebohm 1972, 59. Forster 2010, 2013 daje konceptualnu prednost Herderu temeljeći je i kronološki na utjecaju njegove Rasprave o porijeklu jezika iz 1772. na Hamanna i sve druge romantičare. Forster simplificira Cassirerov prikaz njihovog odnosa u Freiheit und Form iz 1916. (v. Cassirer 1961, 108-115); štoviše, Cassirer eksplicitno ističe Herderovu ovisnost o Hamannu u metakritici kao što je ovisio o Leibnizu u doba traktata o porijeklu jezika (93). Za Herderov pojam metakritike v. noviji zbornik radova M. Heinz (ur.) 2013, u kojemu je Hamannu posvećen 
bi s Herderovim iz 1799., doista nije više od "radnog papira", on daje dovoljan uvid u to da njihovo shvaćanje odnosa um-jezik, koje čini samu srž i posebnost pojma metakritika u odnosu na tada mjerodavan kantovski pojam kritike, nisu istovjetna. To ima značajne posljedice za smisao samog pojma metakritike premda su njihovo polazište i cilj zajednički: obojici je na srcu jezično-teorijska revizija transcendentalne filozofije ili čistog (tj. teorijskog) uma. Upravo suprotno od Adornove ideje metakritike.

Zajedništvo Hamanna i Herdera ostalo je zakriveno kako kronologijom i karakterom njihovih publikacija pod naslovom Metakritika (pismo, knjiga) tako i poviješću nerazmjerne recepcije Herdera. Dok će on sa svojim ogromnim opusom postajati sve slavniji kao kulturno-teorijski i književno-povijesni autor, dotle će zagonentni, autoironični i "lijeni” Hamann, "ljubitelj dosade", gotovo potpuno pasti u zaborav da bi bio ponovo otkriven tek u postmoderni kao jezični filozof, stilist i kritičar prosvjetiteljstva. ${ }^{74} \mathrm{Na}$ takvoj pozadini i Hegelova pohvala Hamannovoj genijalnosti s pokudom za manjak ustrajnosti i otpor prema sistematičnim razradama u teoriji nema tek privatnopsihološki smisao osobne karakterizacije. S jedne strane, ona evocira Hamannovu stvarnu osobnu predfiguraciju literarnog motiva kakav će kasnije napraviti karijeru u romantičkoj književnosti u liku "sretnog dangube”; s druge strane, i svakako važnije, sâma jezično-književna forma kritike imala je već tada reputaciju radikalnosti u osobnom načinu misaono-stilskog odgovora na prosvjetiteljsku kritiku nerada kakvu, primjerice, nalazimo u Kantovoj analogiji između skeptika u filozofiji i "neradnog ljudskog soja” na prvim stranicama uvoda za prvo izdanje Kritike čistog uma. ${ }^{75}$ Međutim, razlika u metakritici između Hamanna i Herdera nije samo kvantitativna, ona je ujedno književno-stilska i konceptualna. Upravo ta je razlika izgubljena padom u zaborav čitave jezično-teorijske kritike Kanta, uključujući i opsežnu Herderovu

jedan rad (v. Bayer 2013). Vidi također prikaz i raspravu o Herderovu pozitivnom odnosu prema Hamannu u Prole 2004, "Metakritika ili parodija?"

74 Također J. Surber 2006, Bayer 2013, Forster 2010, 2013.

75 Književni motiv ilustrira novela Josepha von Eichendorffa "Aus dem Leben eines Taugenichts" [Iz života jednog dangube] iz 1826. Za analogiju između skeptika i neradnika, koja se kod Kanta odnosi na "Indijce pod imenom Cigani”, tj. na Rome, upućujem na svoju raspravu u Mikulić 2019, s opsežnom literaturom. 
Metakritiku, a ne samo maleni Hamannov spis. ${ }^{76}$ To jezično-filozofsko nasljeđe romantike ponovo je otkriveno tek s oživljavanjem interesa za Hegela u 2o. stoljeću, a imalo je posredne posljedice i na ponovno otkrivanje Hamanna u pozitivnom i negativnom smislu. ${ }^{77}$ Stoga i pitanje kvalitativne razlike u pojmu metakritike kod Herdera i Hamanna možemo očitati na povratku metakritike kod Adorna bez nosilaca autorskih prava.

Naime, iako je Adornova Metakritika odmah bila prepoznata kao primjer novohegelijanskog mišljenja 20. stoljeća koje "prisvaja ime 'metakritika', ali pritom ne istražuje odnos prema drugim metakritikama”, kod Adorna se ne radi o pukom prešućivanju historijskog izvora pojma metakritike kao što se ni kod Herdera nije radilo o plagijatu. ${ }^{78}$ Kao i kod Herdera, koji također ne spominje Hamanna, i kod Adorna se radi o promjeni pojma kroz "prisvajanje". Ono o čemu Adorno zapravo šuti, nije tek ime izvornog izumitelja pojma metakritika nego jezično-teorijski karakter i sadržaj metakritike: ono s čime on očito "ne želi biti poistovjećen” (Seebohm) nije toliko Herder, koji je u njemač-

76 U pismima Herderu sâm Hamann naziva svoj rad "svojim jajetom nad kojim leži, svojim Jednim i Svime” (v. Wohlfahrt 1984, 408) ili, opet, "smiješnim mišem, kojeg je brdo konačno porodilo nakon dugotrajnih trudova” i "glupim početkom" (v. Bayer 2013, 66). Taj moment Hamannove samokritičnog priznanja "teškog i oporog stila”, štoviše "prezira prema racionalnoj formi obrazloženja” naspram kojeg se Herderov "briljantni jezični i misaoni stil” pokazuje kao "svjetlo u tami” višekratno ističe Cassirer (2010, 91-93; također 1961, 109, 114). Ipak, o Hamannovu odnosu prema vlastitom stilu najbolje govore "Razgovori pisca sa samim sobom” (v. Bayer 2012, 27-28). Za noviju sistematsku raspravu o odnosu transcendentalne filozofije i teorije fragmentarnosti kod Schlegela, Novalisa i Fichtea v. S. Vlaški 2015. O konfliktima oko formi i stila pisanja članaka u filozofiji i znanostima od 18. stoljeća do suvremenosti v. prilog G. Rujević (ovdje).

77 Lüpke 2004, 5 tvrdi da pojam metakritika, "skovan svjesno u analogiji s pojmom metafizika, ponavlja temeljno iskustvo metafizike”, što ćemo još morati ispitati. O Hamannovoj kritici prosvjetiteljstva v. rane studije Isaiaha Berlina iz 1960-ih u Berlin 2013; novija tematizacija u Betz 2008. Suprotno tome, Bayer 2012 [1988] tumači Hamannovu teološku kritiku prosvjetiteljstva kao njegovu radikalizaciju. Za recepciju Hamanna u postmoderni v. Pupi 1988; za "postmodernu” reaktualizaciju Herdera v. Prole 2004.

78 Seebohm 1972, 6o (bilj. 4). Autor dodaje: "Dok je u doba 'njemačkog idealizma' termin bio nerazdruživo povezan s imenom Herdera (...), sada se izbjegava identifikacija s njime." 
koj samokritici nakon 1945. smatran jednim od stubova njemačkog nacionalizma, koliko suvremena filozofija jezika 20. stoljeća, i to ne samo anglosaksonska analitička filozofija njegovih izbjegličkih godina, nego upravo hermeneutička koja mu je filozofski i kulturno bliskija, napose nakon povratka iz egzila. $U$ tome leži, po mome mišljenju, smisao zagonetne i lapidarne, naoko usputne Adornove opaske kako "metakritika nikada ne prelazi u hermeneutiku”. To znači da Adornovo prešućivanje imena dvojice historijskih protagonista metakritike prešutno sadrži promjenu jezično-teorijskog koncepta metakritike u dijalektički, Hegelov pojam kritike.

No, “anaksimandrovska kletva”, koja će prema Adornu i metakritiku teorije spoznaje učiniti "konstruirajućom refleksijom nužnih grešaka i uzaludnih ispravki”, progovara odatle da je Hamannova jezična metakritika Kantove kritičke teorije spoznaje bez ikakve sumnje već na djelu u samoj srži Hegelove dijalektičke kritike spoznaje na koju Adorno računa. Ona se ne prepoznaje samo $u$ analizi osjetilne izvijesnosti u samom početku Fenomenologije duha, nego je u svojim semiotičkim elementima i pretpostavkama eksplicitno prikazana u tzv. Jenskim sistemskim nacrtima, koji predstavljanju predradnje za Fenomenologiju, i dovršena u trećem izdanju Enciklopedije filozofskih znanosti. ${ }^{79}$

Zato Adornov izbor termina metakritika, usprkos distanciranju od jezične kritike filozofije pod njezinim suvremenim imenom hermeneutike, nipošto nije nevin i jednostavan. ${ }^{80}$ Naprotiv, ako je iz kulturno-historijskih i političkih razloga prešutno izbjegao rizik da bude identificiran s Herderom (Seebohm), način upotrebe izraza metakritika s dovoljnom jasnoćom sadrži aluzivno sjećanje na Hamanna: on je mimetički i izražava se Hamannovim stilom, Hamannovo je ime re-prezentirano i supstituirano riječju metakritika u naslovu Adornovog djela bez opredmećujuće tematizacije termina. Adorno će tek imenovati svoju novohegelijansku dijalektičku orijentaciju metakritikom preu-

79 Za opsežnu diskusiju s daljnjom literaturom upućujem na svoj rad Mikulić 2017.

80 Hegelovsku (dijalektičku) orijentaciju u Adornovoj "metakritici" ističe također Prole 2004, kvalificirajući je s pravom kao kritiku. No, određujući razliku i bliskost između Adorna i romantičara autor nema u vidu jezično-filozofski kriterij i povezuje Adorna s Herderom nejasnim kategorijama. Usp. "Adorno (...) je taj pojam ipak mislio drugačije nego Herder i Haman. Ono što bi moglo da se konstatuje kao zajednička karakteristika Herdera i Adorna kao metakritičara, jeste odbijanje da se na bilo koji način poistovete s predmetom kritike” (191). 
zimajući isti način imenovanja spisa i nesistemski pojmovni model od Hamanna zajedno s njegovim stilom, i gradeći pritom književni korpus filozofije hegelovskih razmjera. Takvu pretpostavku o skrivenom evociranju Hamanna podržava prisustvo Hegelovog imena kod Adorna umjesto Hamannovog. Ni Hegel ne prisvaja Hamannov pojam metakritike iako će iz njezine jezično-teorijske jezgre izgraditi dijalektički sistem filozofije. Štoviše, koliko se Hegel izravno i eksplicitno osjećao bliskim Hamannu (nasuprot Herderu), toliko je Hamannov književni stil nesistemskog mišljenja nedvojbeno djelotvoran u Adornovoj ideji "konstruirajuće refleksije" diskurzivnih kontekstâ teorije spoznaje i u esejističkoj formi filozofiranja.

Moment stila koji povezuje Adornov ne-hermeneutički i Hamannov jezično-filozofski pojam metakritike ilustrirat ću na ovom mjestu primjerkom Hamannove kritike Kanta, koji će nas izvesti ako ne iz anaksimandrovskog kruga ponavljanja "uzaludnih ispravki" teorije spoznaje, onda barem nešto dalje izvan središta vrtnje odakle se mogu sagledati i drugi aspeki Hamanna u suvremenim raspravama. ${ }^{81}$

Brigu analitičke filozofije za "nelječive, invarijantne mane" filozofskih iskaza, nalazimo kod Hamanna na mjestu gdje poetski neologizam empyrizam daje značenje terminu purizam uma metodom spaljivanja. ${ }^{82}$

81 Na ovom mjestu ostavljam po strani pitanje mogućeg Hamannovog udjela u Adornovoj kritici prosvjetiteljstva. Isaiah Berlin 2012, 510 apostrofira taj moment samo na rubu i negativno, kao "davanje utočišta silama tame i obezvređenje prosvjetiteljskog liberalizma” kod "frankfurtovaca i njihovih sljedbenika, napose Foucaulta”. (Vidi noviju raspravu o sudbini Kantove filozofije u romantičkoj kritici prosvjetiteljstva, s posebnim osvrtom na Berlinovu interpretaciju u Krstić 2015.) Betz 2008, 114 navodi također samo na rubu "patologiju i autonasilnost moderne filozofije" u prvoj meditaciji kod Descartesa kao ishodište prosvjetiteljstva. No, pogledamo li detaljnije u Foucaultovo čitanje Kantova pojma kritike kao "umijeća namjerne nepokornosti”, vidimo da ono ne škripi samo u primjeni na Kantovo shvaćanje prosvjetiteljstva i uloge monarha, kako to pokazuje M. Žitko (v. ovdje), nego i na sam pojam kritike. Čini se da Hamannovu metakritiku možemo vrednovati kao životnu formu slobodnog govora ili "parezije" (Foucault), i to kako unutar istinosnog diskursa filozofije tako i naspram akademske i političke dominacije Kantove škole. Dok će prvu slobodu Hamann izraziti stilskim persifliranjem Kanta, ovu izvanjsku će Herder imenovati izravno (v. prikaz u nastavku).

82 Vidi Hamann 1784 [1825], 6: "Der dritte, höchste und gleichsam empyrische Purismus betrifft also noch die Sprache, das einzige erste und letzte Organon und Kriterion der Vernunft." Hamann transformira pridjev 
U svojoj Metakritici Hamann se implicitnim citatom (takoreći “unutrašnjim plagijatom") referira na Kantov iskaz iz popularnog spisa "Prolegomena za svaku buduću metafiziku”, koji je nakon Kantove najave i nestrpljivog Hamannovog iščekivanja izašao 1783., tri godine poslije prvog izdanja Kritike čistog uma. Hamann piše:

"Već na sâmom imenu metafizike visi ta nasljedna mana i guba dvoznačnosti koja se ne može ukloniti, a još manje uzvisiti (verklären) tako da se vratimo do njezina rodnog mjesta koje leži u slučajnoj sintezi jednog grčkog prijedloga." 83

Ta je formulacija zapravo retorička i poetska persiflaža Kantova teksta u kojem Kant također apostrofira "urođenu manu" metafizike:

“(...) u metafizici leži urođena greška koja se ne može objasniti (erklärt), a još manje otkloniti, osim ako se ne uspnemo do njezina rodnog mjesta, samog čistog uma." ${ }^{44}$

Pritom Hamann persiflira sve Kantove izraze, od najbezazlenijeg liegen (ležati) u anhängen (visiti o, nalijegati na), do erklären (objasniti) koji pretvara u verklären tako da uobičajena pozitivna značenja toga glagola (obasjati, uzvisiti, uljepšati, idealizirati) prizovu ne samo plastičnost središnjeg glagola u rečenici ukloniti (heben), nego također i negativnu funkciju prefiksa ver- koji izokreće značenje glagolske osnove (-klär-) u suprotnost (verklären kao mistificirati). Na taj način, jednostavnim jezičnim diverzijama Hamann preokreće smjer i smisao Kantova uspinjanja do "rodnog mjesta urođene greške" u predodžbu silaženja, i pritom ne škrtari ni na hiperbolama o "urođenoj mani” metafizike koju naziva "gubom" (Aussatz).

Pod "slučajnom sintezom” jedne grčke "predriječi” Hamann dakle aludira na sudbinu prepozicije metá iz grčkog jezika u riječi metafizika koja, kako je poznato, predstavlja umjetni neologizam, nastao jezičnim

empirijski (od gr. empeiría) u fantazmatski izraz empyrijski (od gr. pridjeva émpyros, zapaljen, plamteći).

83 Hamann 1784 (1925), 7: "Schon dem Namen der Metaphysik hängt dieser Erbschade und Aussatz der Zweydeutigkeit an, der dadurch nicht gehoben, noch weniger verklärt werden mag, daß man bis zu seinem Geburtsort, der in der zufälligen Synthese eines griechischen Vorworts liegt, zurückgeht”.

84 Kant 1783, 379. “(...) in der Metaphysik [liegt] ein Erbfehler, der nicht erklärt, viel weniger gehoben werden kann, als wenn man bis zu ihrem Geburtsort, der reinen Vernunft selbst, hinaufsteigt." 
deformiranjem izvorne fraze u grčkom 'metà tà physiká' koja je imala editorsku, tj. bibliotekarsku funkciju klasifikacije spisâ i drugačiji smisao. U procesu deformiranja nije nestao samo određeni član srednjeg roda u množini, nego i njegov kolektivni smisao, a "pred-riječ" metá postala je prefiks u apstraktnoj imenici ženskog roda koja označava čitav sektor "transcendentne" stvarnosti, a ne korpus knjiga u biblioteci. Od knjižničarskog termina ostalo je samo to da metafizika označava sadržaje Aristotelovih knjigâ iz prve ili čiste teorijske filozofije o "biću kao biću i onome što mu pripada kao takvom”, koje danas poznajemo pod naslovom Metafizike. Učinak slučajne sinteze je takav da ime metafizike više ne evocira brojnost Aristotelovih knjiga ili mnoštvo njegovih gledišta, nego još samo jedinstvenost apstraktne teorije o umnoj stvarnosti iznad konkretnog svijeta.

Otud metafizika za Hamanna nije samo ime za koncepciju o metapoložaju uma naspram jezika, koja čini podlogu dogme o spontanitetu uma i receptivnosti jezika u ranijoj filozofiji, uključujući i Kantovu. Međutim, odmah ćemo vidjeti da jezgru Hamannova stava kojim on silazi "u rodno mjesto jedne slučajne sinteze" pod imenom metafizike čini ideja koja ne pripada ni u jedan od poznatih modela odnosa um-jezik. Taj stav artikulira znakovnu konstituciju izražajne strane jezika, u osnovi je semiotički i ne odudara samo od primata uma pred jezikom, kakav je vladao novovjekovnom filozofijom do Kanta, nego također i od različitih inačica teorije jezične naravi uma na osnovi koekstenzivnosti um-jezik, kakva će s Herderom zavladati i svim aspektima romantičke filozofije jezika u rasponu od teorijâ značenja do prevođenja i tumačenja. Iako i sam pripada tome krugu, Hamann formulira princip jezičnosti uma na dubljoj i radikalnijoj osnovi:

"Glasovi i slova su dakle čiste forme a priori, u kojima se ne nalazi ništa što pripada osjetu ili pojmu nekog predmeta, i istinski estetski elementi sve ljudske spoznaje i uma. Najstariji jezik bio je glazba, te, pored opipljivog ritma bïla i daha u nosu, otjelovljena praslika svake mjere vremena njezinih brojevnih odnosa".

85 Hamann 1784, 9-10: "Laute und Buchstaben sind also reine Formen $a$ priori, in denen Nichts, was zur Empfindung oder zum Begriff eines Gegenstandes gehört, angetroffen wird, und die wahren ästhetischen Elemente aller menschl. Erkenntnis u Vernunft. Die älteste Sprache war Musik, und nebst dem fühlbaren Rhythmus des Pulsschlages und des Othems in der Nase, das leibhafte Urbild alles Zeitmaaßes und seiner ZahlVerhältniße." (Vidi eng. 211-212.) Za blisko shvaćanje da 
Iz tog naoko bezazlenog iskaza vidimo nekoliko izvanredno značajnih i složenih argumenata, od kojih u ovom kontekstu mogu izdvojiti samo neke implikacije i posljedice za pojam metakritike. Hamannove semiotičke formulacije o apriornim estetskim formama spoznavanja utemeljenje su prioriteta jezika pred umom i pokazuju da on govori o "genealoškom prioritetu" pod vidom jezične konstitucije same umne moći da generira kategorije i razumske operacije. Na tome je postavio dosljedno i radikalno imanentistički promišljen koncept metakritike, iako samo u krajnje sažetom opsegu i pjesničkom izričaju. On nije usmjeren samo protiv Kantova projekta "buduće metafizike", nego također odudara od inače bliskog Herderova modela metakritike. Premda ovdje ne mogu ulaziti u detaljniji prikaz te razlike, ukazat ću na neke stavove koji je dostatno dokumentiraju.

U uvodnim razmatranjima o metakritici Herder se takoreći opravdava za kritiku Kantove filozofije pozivanjem na geslo samog Kanta: "jedini put koji nam preostaje jest put kritike” (xiv), naglašavajući posebno kako se njegova kritika odnosi na spis, a ne na autora. Pritom Herder ironično navodi idolatrijski odnos učenika i uzvisivanja Kritike čistog uma u "spomenik svoga vremena" kao "jedine istinite filozofije", dok se on, sa svojom metakritikom Kanta, obraća "naciji dobronamjernih čitatelja" koja je veća od dominiona jedne filozofske škole. ${ }^{86}$ Međutim, u cijelom metatekstu o metakritici, koji se proteže na bajkoviti prolog o racionalnom i pjesničkom putu uma i na suhoparni uvod, Herder nijednom ne spominje brata-u-metakritici Hamanna, dok naglašeno traži oslonac u jezično-filozofskim motivima kod Platona, Aristotela, Scaligera, Leibniza i napose Lockea, iako navodi samo njihove usputne i mršave reference na jezik; one su Herderu krunski dokaz da jezik u filozofiji nije slabost i konfuzija mišljenja, kao kod Kanta, koje bi se trebalo "stidjeti" nego pripada u filozofiju. ${ }^{87}$ Međutim, ako pogledamo

se kod Hamanna radi o koncepciji jezika kao izvorne estetske moći, a ne strukture, s posljedicama na Hamannovu estetiku u smislu moći suđenja v. ranije G. Wohlfahrt 1984, osob. 414-417; za utjecaj motiva "ritma" na Hegelov pojam mjere te ritmičke versifikacije na koncept "spekulativnog stava” u Logici i Fenomenologiji v. 417, bilj. 120.

86 Herder 1799, xiv: "Von einem Buch ist also die Rede, von keinem Verfasser (...) Denn es ist ein Denkmal der Zeit. Ein Muster kunstreicher Buchstabendichtung (...), das höchste Vorbild philosophischer Ordnung und Kürze, Bündigkeit und Klarheit”. Potom: "Diese kritische Philosophie, sagt man, ist die einzig-mogliche, die einzig-wahre” (xviii).

87 Herder, isto, 7-10 (10). Za širu pozadinu v. Cassirer 2010 (pogl. I. 1-2). 
bolje, čini se kao da kod samog Herdera postoji nešto od jezika što neće postati sastavnim dijelom metakritike transcendentalne filozofije, nešto čega se filozofija ipak stidi: to je upravo najniži, materijalni, semiotički sloj filozofije jezika kakav nalazimo kod Hamanna. Iako ideja znakovnosti svjesti bez sumnje potječe iz Herderove Rasprave o porijeklu jezika iz 1772. i zajednička je svim pripadnicima romantičke filozofije jezika, uključujući Hegela, taj se sloj jezične teorije više ne javlja kao explanans u Herderovoj metakritici Kanta iz 1799., za razliku od Hamannove metakritike iz $1784^{88}$

Razlika leži u karakteru i funkciji semiotičke građe u objašnjenju svijesti.

Za to je karakteristično da sâm Herder već u Raspravi iz 1772. vrednuje funkciju znaka samo pod vidom prirodnog porijekla jezika iz prvog umnog akta čovjeka, protiv tada prevladavajuće teološke teze o božanskom porijeklu i naravi jezika Johanna P. Süßmilcha, ali također i protiv gledišta Condillaca i J.J. Rousseaua o životinjskom porijeklu ljudskog jezika. U Metakritici iz 1799., napisanoj petnaest godina nakon Hamannove Metakritike u formi pisma Herderu, ta će se funkcija znaka kao objedinitelja mnoštva osjetilnog u jedan pojam pojaviti prešutno i u prerađenom obliku pod pojmom tipa (Typus). ${ }^{89}$

Pozadinu Herderova apostrofiranja "stida” od tematike jezika vjerojatno čini Kantovo odbijanje da jezik razmatra u kontekstu transcendentalne analize, ostajući pri shvaćanju jezika engleskih empirista. Vidi Forster 2012, "Kant's Philosophy of Language”, 486, 499.

88 Shvaćanje znaka kao onog što omogućuje sintezu razumske i osjetilne moći i tvori preduvjet spoznaje najizravnije i najpregnantnije izražavaju stavovi Herdera 1772, 39: "Ich habe erwiesen (...), dass nicht der mindeste Gebrauch der Vernunft, noch die einfache, seeliche Anerkennung, nicht das simpleste Urtheil einer menschlichen Besonnenheit ohne Merkmal möglich sey (...) also folgt die Sprache aus dem ersten Aktus der Vernunft ganz natürlich." Nadalje (isto, 66): "da [die] Anerkennung des Mannichfaltigen durch Eins, durch ein Merkmal, Sprache wird, ists Organ der Sprache." Isto, 47: "In mehr als einer Sprache hat also auch Wort und Vernunft, Begriff und Wort, Sprache und Ursache einen Namen, und diese Synonymie enthält ihren ganzen genetischen Urprung”. Tehnički žargon kulminira u svečanom tonu s prizorom "žarišta na kojem Prometejeva nebeska iskra plamti u ljudskoj duši” (isto, 48).

89 Već sami izrazi Typus, Abdruck dovoljni su da prepoznamo ne samo prisustvo Hamannove ideje matrice nego oni vode natrag do Platonovog dijaloga Teetet, u što ovdje neću dalje ulaziti. Herder piše: "Den Typus, den zwischen beiden die Einbildungskraft schuf, den das Gedächtnis 
Međutim, njegova semiotička jezgra ili znakovni element sada je samo implicitni zalog jezičnosti na tzv. "pomoćnim pojmovima" razuma, poput "prijedloga, priloga, zamjenica, nastavaka, pridjeva” poput ispred, iza... koji "staju uz bok" glavnim pomovima kao "koeficijenti, pomagači; pripadajući razumu, pomažu mu u određivanju njegovih pojmova". ${ }^{90}$ Iako pomoćni pridodatak, oni su neporecivi i nužni jezični sastojak razuma kojeg se filozofija, "ne treba stidjeti".

Dakle, iako je Herder bez sumnje u svojoj Raspravi iz 1772. identificirao objedinjujuću funkciju jezičnog znaka kao trećeg vezivnog momenta između osjetilnog i noumenalnog materijala, shvatio je taj prioritet samo kao vid prirodnog porijekla jezika iz prvog akta razuma. Tu ideju prirodnosti nalazimo ponovo u Metakritici iz 1799., ali u izmijenjenom teorijskom ruhu: semiotička konstitucija uma na znakovnoj razini jezika izgubljena je iz vida podizanjem "izvora" na razinu i kategoriju riječi; leksik i gramatika, tj. definirane jezične veličine i pravila, sad čine nužni pomoćni jezični pojmovnik bez kojeg razum ne može funkcionirati: jezik je dobio status nužnog, a ne više slučajnog suplementa na starijoj matrici prioriteta razuma. Iz toga je dovoljno razvidno da Herder u Metakritici želi, pomirljivo prema Kantu i nastavljajući se na Kritiku čistog uma, samo rehabilitirati (osvijeliti, uzvisiti) jezični aspekt na razumskom aparatu koji je u filozofskoj tradiciji potisnut, a za čije svjedoke poziva Lockea i Leibniza. Na toj

aufbewahrte, den die Erinnerung weckt und mancherlei Zufälligkeiten modifizieren, er war weder Empfindung noch Begriff allein, sondern der Abdruck beider" (1799, I. 293).

90 Herder 1799, I. 284-285. Na tome mjestu Herder komentira Kantovu "tablu kategorija" iz KrV SS 9-10 asocirajući ih s prepozicijama ili "predriječima”: "Nicht anders als also haben sich diese Hülfsbegriffe der einen großem Verstandesoperation auch in die Sprache eingeführet. Als Präpositionen und Adverbien, oder als Pronomina, Endungen, Adjektive stehen sie den Hauptwörtern zur Seite, vor und nach (...) Koefficienten des Hauptbegriffs, Helfer (...) dem Verstande zugehörend, helfen [sie] zu Bestimmung seiner Begriffe." - Odatle vidimo da Herder, rečeno u Cassirerovim terminima, zapravo opisuje "gramatičku zgradu jezika" ("der grammatische Bau der Sprache") na razini razumskih kategorija (Cassirer 1910, 89). Štoviše, Herder zapravo preuzima (i oslabljuje) Lockeovo i Leibnizovo "otkriće” jezičnih "partikula“ (tj. autonomno jezičnih, sinkategorematskih izraza bez referencije), zbog kojih jezik izvorno, a ne sekundarno, konstiruira moć razuma. Vidi prikaz u. McRae 1988. Za pragmatičko prevrednovanje Lockeova teorije jezika v. Lenz 2010. 
osnovi Herder će ispostaviti generalnu tezu o podudarnosti ili paralelizmu (koekstenzivnosti) razuma i jezika, ali neće dovesti u pitanje ni primat razuma pred jezikom niti samu ideju apriornog uvjetovanja spoznaje. ${ }^{11}$ Štoviše, kao što u Raspravi iz 1772. jezik izvire iz prirodnog akta razuma, u Metakritici iz 1799. jezik, kao dodana vrijednost razuma, preuzima istu naddeterminirajuću funkciju transcendentalnog uvjeta a priori kakvu kod Kanta imaju pojmovi i kategorije čistog razuma. One su, prema Herderu, operativne kao razumske kategorije tako što su nužno jezične, a ne slučajno i naknadno. Međutim, u Metakritici ne saznajemo i zašto su nužno jezične. Razlog tome, koji nalazimo u Raspravi iz 1772., očito više ne pripada u domenu koje se kritička filozofija ne bi trebala stidjeti.

Time nova metakritika filozofije, iako uzima vid jezično-teorijske kritike, ponavlja koncept naddeterminirajuće instance i pretvara umno-transcendentalni apriori u jezično-historijski apriori. Taj će proces, posredstvom pojačivačâ poput Friedricha Schlegela i osobito W. von Humboldta, kulminirati kasnije kod Nietzschea u shvaćanju jezika kao skupa funkcija i invarijabilnih značenja koji iznutra stvaraju jezične "obiteljske sličnosti sveg indijskog, grčkog i germanskog filozofiranja”, dok izvana, na teorijskoj razini, daju dvostruko determinističku, darwinističku i kulturalističku, formulaciju primata jezika. ${ }^{92}$ To je koncepcija koja će, preko Wittgensteinove afirmacije

91 Kako Herder izričito ističe već u uvodu, nije mu namjera prekoračiti granice jezičnosti kod Leibniza i Lockea: "Glaube niemand, daß die hohe Kritik der reinen Vernunft hierdurch erniedrigt, und die feinste Spekulation zur Grammatik werde. Es wäre gut, wenn sie in allem dies werden könnte: worauf auch Leibniz mit seiner Charakteristik ausging” (isto, I. 8). Zato kod Herdera i na semiotičkoj razini "osjetilnog pojma” primat ipak zadržava razum: "Dem alten Spruch: Nichts ist im Verstande, was nicht im Sinn War, kann und muss man seinen Gegenspruch beifügen: bei Menschen giebt es keinen sinnlichen Begriff, an welchem nicht der Verstand Theil hatte und ihn formte" (isto, I. 292).

92 F. Nietzsche 1882, Die Fröhliche Wissenschaft, $\mathbb{S} 354$. Riječ je o općem teoremu romantičara koji će, polazeći od jezično-deskriptivnog rada Friedricha Schlegela na sanskrtu i indijskoj filozofiji (Über die Sprache und Weisheit der Inder. Ein Beitrag zur Begründung der Alterthumskunde iz 18o8.), razviti W. v. Humboldt u komparativnim istraživanjima indoevropskih i azijskih jezika, a kasnje će postati poznatiji u lingvistici pod imenom Whorf-Sapirova hipoteza. Za kasniji utjecaj Nietzscheova strukturalno-jezičnog determinizma kako na Wittgensteinov asubjektivizam i analitičku filozofiju tako i na neostrukturalizam kod 
antiindividualizma jezika i Heideggerove analitike strukturâ tubitka iz kasnih 1920-ih, zavladati antifilozofskim i antihumanističkim metadiskursom filozofije 1960-ih, u različitim izvedenicama, od strukturalističke rekonstrukcije filozofskih ideja na matricama jezičnih i religijskih institucija, preko genealogije režimâ episteme i diskursa do hermeneutičko-pragmatičke verzije kritičke teorije u metafilozofskim analizama transformacijâ filozofije. ${ }^{93}$

Nasuprot takvom razvoju eksternalistički shvaćenog prioriteta jezika koji ponavlja model prioriteta razuma, o imanentizmu Hamannova shvaćanja metakritike rječito govori već okolnost da ona nije predmet posebnog, obrazlažućeg i objektivirajućeg diskursa, kako je to slučaj kod Herdera u naglašenom isticanju logičkog porijekla metakritike iz kritike kritike. ${ }^{94}$ Naprotiv, njezin meta-karakter prikazan je u samom

J. Lacana i J. Derride v. Manfred Frank 1984, Was ist Neostrukturalismus? (osob. 13. pred.).

93 Mislim dakako na radove E. Benvenistea, J-P. Vernanta, M. Foucaulta, $\mathrm{K}-\mathrm{O}$. Appela i dr. Za ambivalentni status filozofije kod kasnog Foucaulta v. prilog M. Žitka (ovdje); v. također osvrt na metodološki "alternativnu" povijest filozofije u posljednjem opus magnum J. Habermasa u Čačinovič (ovdje).

94 Na takvoj pozadini dijagnoza o "ponavljanju iskustva metafizike" u samom konceptu metakritike (Lüpke 2004) čini mi se krajnje upitnom u Hamannovom slučaju. Ona možda bolje opisuje razvog filozofije jezika kao nove simboličke metafizike od Herdera do Cassirera. Slično Prole 2004, 181: "Nije potrebno potcrtavati da je ovde na delu upadljiva protivrečnost: ukoliko jezik u samom sebi nije umski strukturiran, tj. ako bi jezik karakterisalo potpuno odsustvo uma, onda ne može biti jasno ni kako bi jezik mogao biti konstituens uma?" Takvo se proturječje pojavljuje ako previdimo temeljnu razliku između semiotičkog i gramatičkog (sintaktičkog) aspekta jezika za koje autor nediskriminativno koristi opći termin jezik. Ali u tom vidu, problem se javlja u odnosu na Herderov koncept "primata" jezika" koji, kako sam naprijed nastojao pokazati, zapravo zadržava primat uma, jer je jezik "koeficijentni” karakter ili "konstituens" samih razumskih kategorija, a ne Hamannov genealoški primat koji računa na kapacitet jezika da iz estetskih matrica, sazdanih od malo elemenata i njihovih relacija, generira potencijalno beskonačnu količinu umnih (razumskih) radnji. Tek odatle možemo, čini se, bolje razumjeti jesu li um i jezik heterogene ili homogene strukture ili je dilema prividna, donosi li ispitivanje jezika nešto novo u odnosu na um, i obrnuto, je li um, ako je produkt jezika, nužno i njegov "nesavršen odraz" te zašto kod Hamanna zapravo "nema nepovjerenja prema umu" nasuprot baštinicima od Schopenhauera i Nietzschea do postmoderne (isto, 181-182). 
aktu teorije, kroz semiotički teorem kojim se otkriva znakovni korijen same umnosti, a ne status trećeg, veznog momenta koji objedinjuje mnoštvo osjetilnog u jednotu pojma, a još manje pomoćni karakter jezičnih koeficijenata na razumskim odredbama: sam jezični korijen uma je ono što generira razumske radnje iz prostorno-vremenskih matrica i obrće odnos porijekla: ne potječe jezik iz prvog umnog čina, kao kod Herdera, nego je znakovni jezični akt ono što realizira umnu sposobnost. Nije, dakle, riječ o posebnoj instanci koja s onu stranu uma dopunjuje um. Naprotiv, jezik je sâmo središte u kojem moramo tražiti razrješenje "nesporazuma uma sa samim sobom". ${ }^{95} \mathrm{Iz}$ navedenog, slikovito nabijenog djelića teksta vidimo točno što to za Hamanna znači: apriorne kategorije vremena i prostora, koje čine temelj Kantove kritike, zapravo su semiotički entiteti složeni od glasova i slova, ritma, ponavljanje, razmaka i brojevnih odnosa ili mjere. Time je jezik, taj empirijski i historijski element u svome najmaterijalnijem aspektu znakovnosti, koji je Kant isključio iz transcendentalne analize, uveden u sâmo srce transcendentalnog shematizma, kao konstitutivni i formativni materijalni moment samih kategorija i pojmova. ${ }^{96}$ Oni su "utjelovljene praslike" i "matrice sveukupne osjetilne spoznaje", koje sadrže "ekonomiku prostora”, kako nam to, prema Hamannu, pokazuju figure najstarijeg pisma — slikarstvo i crtež. ${ }^{97}$ Ono što je Hamann

95 Hamann, isto, 9: “(...) so braucht es keiner Deduction, die genealogische Priorität der Sprache vor den sieben heiligen Functionen logischer Sätze u Schlüße, und ihre Heraldik zu beweisen. Nicht nur das ganze Vermögen zu denken beruht auf der Sprache (...): sondern Sprache ist auch der Mittelpunct des Misverstandes der Vernunft mit ihr selbst, Theils wegen der häufigen Coincidenz des größten und kleinsten Begriffs, seiner Leere und Fülle in idealischen Sätzen, theils wegen des unendlichen [Vorzugs] der Rede vor den Schlußfiguren, und dergl. viel mehr”. Izraz "koincidencija najvećeg i najmanjeg pojma, njegove praznine i punine", odnosi se na najopćenitije pojmove s najvećim dosegom, putem kojih se realizira idealizacijska i apstrakcijska moć jezika da se odnosi na svaki predmet i svako stanje stvari (v. Bayer 2013, 75).

96 Bayer 2013, 69 shvaća status dedukcije kategorija posve obrnuto, kao subjektivnu stranu čiji jezični karakter tek treba pokazati, dok za objektivnu dedukciju, koja se odnosi na empirijski karaker jezika, smatra da se to pitanje uopče ne postavlja za Hamanna, odnosno da je riješeno u pojmovniku historijskih jezika, tj. semantičkim zalihama, jer "svi pojmovi su za Hamanna jezični, te otud počivaju na iskustvu i posjeduju intenziju i ekstenziju reguliranu preko nasljeđene jezične upotrebe”.

97 Hamann, 1784, 10: "Die älteste Schrift war Malerey und Zeichnung, 
1784. nazvao matricama, Herder će u svojoj Metakritici 1799. nazvati platoničkim žargonom typus, otisak. Međutim, iz njega je nestao izvorni semiotički potencijal za proizvodnju značenja. Zamjenjuju ga sada njegovi proizvodi: riječi koje su sada nosači već definiranih značenja o kojima "vise" (anhängen) pravila njihove upotrebe. Razum je forma iz koje je nestalo sjećanje na jezik, na "karakteristiku" uma, i treba mu vratiti njegovo pravo ime gramatike. ${ }^{98}$ Razum je jezična slika svijeta.

Nasuprot tome, ono što kod Hamanna čini sâmo metá na kritici, odnosno njezin rubni ili opkoračujući karakter, a što kod Herdera služi ili kao dokaz o prirodnom porijeklu jezika ili o jezičnom porijeklu razuma, jest raskrivanje konstitucije same umne moći. To nije jezični aspekt razumskih kategorija, nego jezik u njegovoj elementarnoj semiotičkoj jezgri znaka koja omogućuje artikulaciju, tvorbu značenja i koja uopće generira govor, pa tako i govor o samome sebi, metakritiku. ${ }^{99}$ Metakritika dakle nije refleksivna samo tako da još jednom reflektira refleksiju kritike, kako Herder opisuje svoj odnos prema Kantu. Metakritika je refleksivna zato što je forma autopoieze: princip koji ona ispostavlja teorijski, princip je njezina samoizvođenja. Ona je refleksivna zato i tako što je autoperformativna. Dakle, ono što čini njezinu metapoziciju, djeluje iznutra, iz same pozicije. Otud, Hamannova ironija prema "urođenoj mani samog imena metafizika", koje je samo "slučajna sinteza jedne grčke prepozicije", ukazuje iznova na problem imanentizma metakritike i zadobiva dodatnu vrijednost

beschäftigte sich also eben so frühe mit der Oekonomie des Raums, seiner Einschränkung und Bestimmung durch Figuren. Daher haben sich die Begriffe von Zeit und Raum durch den überschwenglich beharrlichen Einfluß der beyden edelsten Sinne, Gesichts und Gehörs in die ganze Sphäre des Verstandes, so allgemein und nothwendig gemacht, als Licht und Luft für Aug, Ohr und Stimme sind, daß Raum und Zeit wo nicht ideae innatae, doch wenigsten matrices aller anschaulichen Erkenntnis zu seyn scheinen."

98 Karakteristično, Herder se u svome evociranju Lockea (Herder 1799, 9) referira na "Pismo čitatatelju" uz peto izdanje Eseja o ljudskom razumu koje sadrži Lockeov metajezični komentar, ali ne i na završnicu o

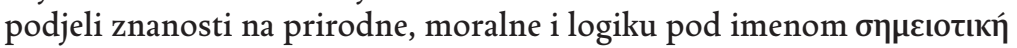
(semeiotiké) gdje Locke analizira ideje uma pod vidom znakova (signs), v. Book IV, Ch. XXI. 4. Of the Division of the Sciences.

99 Taj locus izražava Aristotelov pojam 'hermeneîa' (artikulacija, izricanje, iskazivanje), koja predstavlja jedan od najopćenitijih graničnih pojmova Aristotelove teorije jezika i filozofije uopće; ona nigdje nije predmet definicije nego je uvijek samo definiens. 
za raspravu. Ona blokira u začetku proliferaciju metarazinâ kakva se manifestira između Herdera i Kanta u nominalnom kontinuitetu kritikâ.

Naime, budući da se već sama Kantova kritika odvija kao konceptualna kritika stare metafizike s ambicijom da postane nova metafizika, a seže od analize uvriježenih pojmova preko intuicijâ do riječi i fraza iz prosječne jezične upotrebe - što je in nuce ne čini samo tipičnim analitičkim postupkom u filozofiji koji svaki put, od Elejaca do Wittgensteina, donosi "zaokrete" u filozofiji, nego također otvorenom i za prirodno-jezični tip kritike kakav je Locke smatrao nužnim za posao filozofije i posvetio mu poseban dio Eseja ${ }^{100}$ — na takvoj pozadini više je nego očigledna opasnost od proliferacije metajezika ili metadiskursâ. Ona je na djelu u podnaslovu Herderova dvodjelnog spisa iz 1799. "Eine Metakritik zur Kritik der reinen Vernunft", a potvrđuje ju njegova izričita opaska kojom vjeruje da je problem i riješen: polazeći od Kantova stava da je jedini put koji nam preostaje put kritike, pri čemu jedino stanovište s kojeg se može kritizirati um jest sâm um, Herder zaključuje kako nam ne preostaje drugi put do kritike Kantove kritike osim same kritike: ona se sad mora zvati metakritikom, tako da ime "objašnjava samo sebe". ${ }^{101}$ Metakritika nije zapravo ništa drugo do

100 Vidi Locke 1690 (1975), 10: "Vague and insignificant forms of speech, and abuse of language, have so long passed for mysteries of science; and hard and misapplied words, with little or no meaning, have, by prescription, such a right to be mistaken for deep learning and height of speculation, that it will not be easy to persuade either those who speak or those who hear them, that they are but the covers of ignorance, and hindrance of true knowledge. To break in upon the sanctuary of vanity and ignorance will be, I suppose, some service to human understanding; though so few are apt to think they deceive or are deceived in the use of words; or that the language of the sect they are of has any faults in it which ought to be examined or corrected, that I hope I shall be pardoned if I have in the Third Book dwelt long on this subject, and endeavoured to make it so plain, that neither the inveterateness of the mischief, nor the prevalency of the fashion, shall be any excuse for those who will not take care about the meaning of their own words, and will not suffer the significancy of their expressions to be inquired into."

101 Herder 1799, I. Theil, xiii-xiv: "Metakritik also; der Name erkläret sich selbst. 'Der kritische Weg ist allein noch offen', und vor Ablauf des Jahrhunderts, wo alles geendert seyn muß, soll jeder dazu das Seinige beitragen, sagt der Verfasser der Vernunftkritik selbst. Metakritik zur Kritik der reinen Vernunft; von einem Buch ist also die Rede, von keinem Verfasser. Noch weniger von eines Verfassers Gaben und Absicht; sondern von eines Buchs Inhalt und Wirkung." (Herderov citat, 
kritika kritike, baš kao što je za postanalitičke filozofe metafilozofija filozofija filozofije. Međutim, gledajući iz Hamannovog pojma metakritike, to govori protiv Herdera: njegova metakritika Kanta proizlazi iz same Kantove kritike čistog razuma, a ne protiv nje. Jezik je samo aspekt razuma, leksika i sintaksa, a ne njegov dublji princip. To je mogući razlog da Hegel izbjegava i sâm termin metakritika i upisivanje u literarnu modu (“invaziju”) pod tim "brandom”.

Otud, Herderov prikaz geneze pojma metakritike kroz tautološko udvostručenje "kritika kritike" sugerira da Herder ostaje takoreći "u granicama razuma”, odnosno da u spisu Metakritika iz 1799. matrica razuma određuje granice shvaćanja jezika. To znači, Herderova metakritika nije, za razliku od Hamannove, toliko primjena njegove vlastite semiotičke genealogije jezika iz Rasprave o jeziku na Kantovu Kritiku čistog uma, koliko retrogradno prevođenje Hamannovog pojma metakritike na Kantov pojam kritike kroz tautološki udvostručen koncept kritike kritike: iako se deklarira kao jezična, ona je kritika razuma samim sobom kroz priznanje nužnosti jezičnih "pridodataka" ("koeficijenata”, "priroka”, "predriječi”) kao svojih vlastitih karakteristika kojih se "ne treba stidjeti”. Pritom, međutim, rečeno Hamannovim riječima, um pod vidom razuma "ponavlja nesporazum sa samim sobom” o svome primatu. Zato se genuini jezični karakter Hamannove metakritike i smisao naslova njegova epohalnog teksta vidi samo u sadržaju: znakovna sinteza prostorno-vremenskih matrica jezična je pretpostavka sâme umne moći. Hamannova metakritika je ta koja nasljeđuje i primjenjuje Herderovu Raspravu iz 1772. u njezinu elementarnom i radikalnijem semiotičkom aspektu od Herderove vlastite metakritike koja postaje prikaz strukture razuma u njegovim danim jezičnim formama - u aktualnim, vladajućim kategorijama, pojmovima i sudovima. Produkcija samog razuma iz jezičnih znakovnih sinteza

Kritik der reinen Vernunft, S. 884. Zweite Auflage.) Nadalje, 4-5 (5): "Endlich muß sein Urtheil selbst klar, gewiß, aus dem Gegebenen nach der ihm gegebenen Norm entsprungen seyn; oder es wird geläutert. Jede Läuterung unterwirft sich denselben Gesetzen; und da der Verfasser der Kritik der reinen Vernunft seine Schrift als das Werk anführt, 'welches das reine Vernunftvermögen in seinem ganzen Umfange und Grenzen darstellt, so kann es und darf nicht anders als mit Prüfung, d.i. kritisch gelesen werden'. Die Anmerkungen, die daher entspringen, können keinen bescheideneren und eigenern Namen als Metakritik, d.i. Kritik der Kritik führen." (Herderov citat odnosi se na: Prolegomena zu einer jeden Metaphysik, die als Wissenschaft wird antreten können, Riga 1783, Vorrede, S. 14). 
bit će zamijenjena leksikom i gramatikom i pasti u teorijski zaborav. ${ }^{102}$ Otud kod Hamanna termin metakritika nije predmet teorijski opredmećujućeg metajezičnog komentara, nije objašnjen genealoški iz tautološkog koncepta kritike uma kritikom uma nego je izravno izveden metakritičkim mišljenjem kroz sadržaj spisa. On je u svome središnjem iskazu semiotički.

Ta naoko teško uhvatljiva i malo značajna razlika između dviju metajezičnih operacija (prevođenja kategorija razuma u kategorije jezika kod Herdera i prikaza semiotičkog korijena umnosti kroz sam semiotički teorem o apriornoj funkciji znakova kod Hamanna), omogućuje nam da Hamannov naizgled formalni, prazni termin metakritika, prepoznamo kao suprotan njegovom tautološkom prijevodu u izraz kritika kritike kod Herdera. Kod Hamanna se metakritika javlja u statusu "slobodnog označitelja" u njegovoj autoreferencijalnoj strukturi i autopoietičkoj funkciji, u doslovnom smislu autonomnog samoproizvođenja referenta (označenog) kroz samo-označavanje označitelja: izričući samo svoju topiku (metá) i postupak (kritika), izraz uprizoruje takoreći ono na što se terminološki odnosi; sam označitelj je prizor akta samoproizvođenja označenog, primjerak ili reprezentant jezika u njegovoj metajezičnoj i poetskoj funkciji. Upravo to je ono što omogućuje i Herderov metalingvistički prijevod pojma metakritika u frazu 'kritika kritike'. Ali sad vidimo da to ne važi obrnuto: dok Hamannova semiotička formula apriornog omogućuje metadiskurs, Herderova se kritika kritike ne može prevesti u Hamannovu metakritiku bez zamjene gramatike semiotikom. To isto će omogućiti, $s$ druge strane, Hegelu da izbjegava termin metakritika dok masivno preuzima i razrađuje Hamannove zgusnute i nesistematske, pjesničke teorije jezika kao "rodnice uma". Gotovo istovjetan ambivalentni stav

102 Ovo gledište ne dovodi u pitanje kronološki i jezično-teorijski prioritet Herderove Rasprave o jeziku 1772., na čemu inzistira Forster (2010, 2013). Radi se o prioritetu i specifičnosti Hamannovog pojma metakritike. On počiva na semiotičkom aspektu teorije jezika, koji Forster ignorira čak i kod samog Herdera, favorizirajući semantičko ishodište "triju revolucija” u teorijama značenja, prevođenja i tumačenja. Za razliku od toga, Cassirer, na kojeg se Forster zapravo oslanja, daje prednost Herderu u dimenziji sistematskog racionalnog prikaza teorije, kojemu i sam teži, iako za ishodišnu tezu same metakritike o jezičnom (znakovnom) "korijenu uma” jednoznačno daje prednost Hamannu (Cassirer 2010, 92-93). Još izraženije je, prema mome razumijevanju, Cassirerovo oslanjanje na Hamanna u Metafizici iz zaostavštine, gdje evocira samo uopćeno formulu o poeziji kao "maternjem jeziku ljudskog roda" (1995, 112). 
i izbjegavanje termina prepoznaje se, prema mome uvidu, u Cassirerovu odnosu prema Hamannu i Herderu. Dok cijeni Herderovu sistematičnost $i$ jasnoću jezično-kulturne teorije svijesti kao kantovsku kvalitetu kritike, Cassirer, kao i Hegel, crpi iz Hamannove genijalne i opore spekulacije o izvoru uma u formi jezične sinteze osjeta koju će u Metafizici iz zaostavštine investirati u analizu pojma djelo (Werk) kao "trećeg bazičnog fenomena" koji konstituira subjektivnost. Iako sâm pojam djela deklarativno preuzima iz Goethevih "Maxima" i Fichteova pojma djelatne radnje (Tathandlung), ono što utire put Cassirerovoj ambiciji da izradi poietički smisao "metafizike semiotičkih oblika" (1995) jest Hamannovo "silaženje” u semiotički temelj uma kao praktičkog akta sinteze u kojem se subjekt u samom začetku uspostavlja kao svoje objektivno drugo u svijetu, a ne introspektivno. No, dok tu poietičku funkciju traži u teoremu o pojmu 'djela', ne prepoznaje ga u Hamannovu poetskom djelu metakritike koje se gradi iz svih diskurzivnih registara, od poetskih i retoričkih preko esejističkih do traktata. Nasuprot tome, Hamann će, kao antipod ili antiheroj Hegelove, Herderove i Cassirerove sistematičnosti u izlaganju, omogućiti Adornu da pod terminom metakritika prakticira u teoriji stilsko mišljenje uz masivno odricanje od njegove jezično-teorijske osnove. Još dalje gledano, navedena mala velika razlika u smislu i pojmu metakritike omogućuje da Herderovo prevođenje 'metakritike' u kritiku kritike vidimo na pozadini suvremenih analitičkih i postanalitičkih filozofa, od Lazerowitza do Reschera, angažiranih u sporu oko "metafizičkog" karaktera metafilozofije i oscilaciji između eksternalizma i imanentizma pojma. Sve to je, po mome uvjerenju, derivat teorijskog ishodišta koje Hamann dočarava metaforom "maternice uma”, ali ga - ništa manje jasno i razložno - prikazuje u pojmovima "transcendentalne semiotiče analize” kakvoj će Cassirer težiti u metateorijskim spisima o filozofiji simboličkih formi pod omraženim naslovom "metafizika”.

\section{Metoda 'intervencije’: Aristotel i teorija teorije}

Hamannova opaska o "slučajnoj sintezi jednog prijedloga" upozorava nas da termin metakritika nije skovan, usprkos očekivanju, po analogiji s terminom metafizika i ne označava neko stanovište iznad ili povrh filozofije koje omogućuje suveren pogled na cjelinu i objektivira je u totalitet. Kako smo vidjeli, metakritika je kod Hamanna ime za semiotičku formulu o samoizvođenju umnog akta iz materijalnih jezičnih elemenata koji tvore prostorne i jezične forme (matrices), tj. za procese semioze koja iznutra stvaraju umni govor. Metakritici, 
stoga, nije potrebna izvanjska pomoć, poput Kantove transcendentalne dedukcije kategorija, da bi otkrila nesporazum "čistog" uma sa samim sobom o svome spontanitetu nasuprot receptivitetu jezika, o prvenstvu kategorija "čistog razuma” pred jezikom i tako izliječila "gubu metafizike". Štoviše, transcendentalna ili čista dedukcija samo je još jedan oblik gube, kao i Herderova "kritika kritike" koja uparuje razum i gramatiku. Svaka je inačica iste bolesti koja dolazi iz "slučajne sinteze jednog grčkog prijedloga”.

Poučeni Hamannovom lekcijom, prijedlog metá, kako je "sintetiziran" u izrazu metafizika i odatle prenesen na pojam metafilozofije, ne smijemo više čitati na matrici pojma i izraza metafizika, tj. u rekciji s akuzativom, prema sintaktičkoj konstrukciji i značenju fraze u starogrčkom 'metà tá physiká, koja je označavala editorsko mjesto knjigâ prve ili teorijske filozofije u korpusu Aristotelovih spisa, "iza fizikalnih tema”. Takva leksikonska pozadina tvori nereflektiranu na-

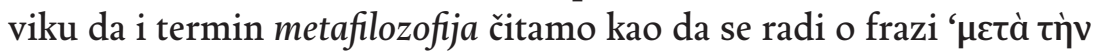
фıһобофíav' (iza/iznad filozofije) u hijerarhijskom poretku odnosa, bilo da je shvaćen horizontalno (iza) ili vertikalno (iznad). ${ }^{103}$

Iako ova tematika premašuje okvire deskriptivne gramatičke analize, na širi konceptualni kontekst mogu ovdje podsjetiti samo na rubu. Hijerarhijski topički opis prepozicije metá u terminu metafilozofija, koji ujedno izražava vrijednosni status, može u povijesti filozofskih ideja odgovarati samo teološkoj liniji kasnije novoplatoničke i skolastičke filozofije, ali ne nužno mjestu i karakteru tzv. "teološke” filozofije u XII. knjizi Aristotelove Metafizike pa ni Platonovom konceptu sinoptičke spoznaje u VII. pismu. Naime, dok kasnija razvojna linija kvalificira diskurzivnu teorijsku refleksiju filozofije (theōría kao sképsis) kao nižu i podređuje je odozgo "višem", kontemplativnom obliku spoznaje kakva odgovara višoj stvarnosti božanskog bića, ni Platonova teorija dijalektike, a još manje Aristotelov analitički postupak u diskursu prve filozofije, uključujući i teološki, ne dopušta redukciju intelektualnog karaktera spoznaje na intuitivni um lišen diskurzivnosti. ${ }^{104}$ Teološki

103 Za rekcije priloga metá s akuzativom i genitivom te različite smislove njegove prostorne i vremenske upotrebe u starogrčkom v. LSJ 1982, s.v. Tu razliku s pravom smatraju bitnom Reese 1999, 28 u odnosu na Lazerowitza i P-L. Assoun u vezi s Freudovim terminom metapsihologija (v. naprijed citirano mjesto, Assoun 2013, 69).

104 Vidi diskusiju o karakteru umnog udjela u spoznaji prvih principa u Aristotelovoj Drugoj analitici (Anal. Post., B 19) Barnes 1993, 259-271 (267-268). 
diskurs filozofije kod Platona i Aristotela sistematski je izdanak racionalne metode spoznaje (dijalektičke, odn. analitičke) i sastavni dio filozofije, a ne transcendentno meta-stanovište s kojeg se izvana ili odozgo određuju vrijednost i mjesto filozofije. O tome, usput rečeno, rječito govori povijest metajezičnog razumijevanja pojma speculatio, počevši od Aurelija Augustina i kasnijih teoloških filozofa, preko mističke teologije Meistera Eckharta i njemačkog idealizma sve do suvremenih pokušaja reafirmacije toga pojma u kritičkom marksizmu od 1960-ih kod Adorna, Marcusea ili, kod nas, Milana Kangrge. Iako termin speculatio predstavlja latinsku prevedenicu za grčki izraz theoría, povijest speculatio odražava (historijski sekundarnu) podjelu na novoplatoničko shvaćanje teorije kao motrenja svijeta božjim okom iznutra, po modelu ogledala (speculum), i skolastičko-aristotelovsko gledišta izvana, po modelu osmatračnice (specula), kako je tu razliku formulirao Augustin. ${ }^{105}$

Ta se tradicionalna podjela ponavlja, kako smo mogli vidjeti, na dvama modelima metakritike. Jednom na modelu opredmećujuće kritike kritike kod Herdera, koja prepoznaje transcendentalni aparat čistog razuma na razini gotovih formi (leksika i sintakse) aktualnog jezika (njemačkog); drugi put na modelu autopoetske funkcije jezika kod Hamanna koja sintetizira materijalne elemente jezika (glasove, slova, ritam, razmak) u matricu koja iz sebe generira jezični akt kao diskriminativni akta uma i uvijek nov govor koji nije tek replika razumske kategorije. Međutim, navedena podjela na izvanjsko-nutarnje ne može se, po mome mišljenju, potvrditi na shvaćanju metafilozofije pod vidom metode u klasičnoj konceptualizaciji kod Aristotela i Platona.

To vidimo odmah ako prijedlog metá uzmemo u genitivskoj rekciji umjesto na matrici umjetnog izraza metafizika, tj. ako metafilozofiju čitamo kao derivat prirodnog jezičnog oblika - metà philosophías. Tek u takvom čitanju, metafilozofija se uopće može pojaviti u prirodno-jezičnoj bliskosti s drugim poznatim terminima filozofije umjesto da je svodimo na neologizam metafizika koji je sintaktički izobličen i semantički falsificiran u drugom jeziku da

$105 \mathrm{Za}$ detaljan pregled jezične i konceptualne povijesti v. natuknicu u HWPh 1995, sv. 9, s.v. Spekulation. Vidi posljednju knjigu Milana Kangrge 2010, koji datira spekulativnu filozofiju s transcendentalnim idealizmom kod Fichtea, ali je, slično kao i Rescher metafilozofiju, nalazi u neosviještenom stanju u pojedinim filozofemima od Heraklita do Spinoze, da bi se kao pojam ponovo izgubila kod Marxa, iako je tek tu na djelu. 
bi postao pseudo-grecistička himera i glavni termin u pojmovniku cijele zapadne filozofije. Umjesto hijerarhijskog smisla iznad, povrh, iza, nakon (koji svi prenose rekciju prijedloga metá s akuzativom), genitivska rekcija prijedloga posreduje horizontalni, socijativni i sintagmatski odnos elemenata, kakav prevodimo prepozicijama $s a, u$, posred, među, a nalazimo ga u prirodno-jezičnom repertoaru grčkog jezika u glasovitom izrazu méthodos. Metafilozofija nas već iz jezičnohistorijskih razloga upućuje najprije na metodu, u terminološkom i pojmovnom značenju toga izraza.

Da bismo razumjeli pojam i termin méthodos, nije potrebno rastavljati ga vještački na sastavne dijelove [metá + hodós], kako se to obično čini. Izravnije i ispravnije može se razumjeti na obrascu prirodno-jezične fraze metà hodoû u prosječnoj upotrebi koju shvaćamo i prevodimo, ovisno o kontekstu, izrazima na putu, putem, usput. Povrh toga, tek fraza metà hodoû vodi nas dalje do sintaktički i semantički najsrodnijih jezičnih oblikâ u retorici klasičnog diskursa filozofije, $s$ istom prepozicijom u genitivskoj upotrebi i s horizontalnom topikom i socijativnim smislom: to su fraze metà lógou i dià lógou koje plijene pažnju širokim rasponom značenja i primjenom na logiku, metodologiju i retoriku diskursa gdje najčešće lociramo rane metametodološke refleksije, a prevodimo ih frazama s razlogom, obrazloženo, opravdano, kroz govor, s govorom. Ona nas izravno dovodi do figure obrazloženja u njezinoj najpoznatijoj jezičnoj verziji lógon didónai (dati razlog) i dovodi u pitanje uvriježeno razumijevanje te fraze o utemeljenju znanja na metafizičkom diskursu istine. Osim normalno-jezične upotrebe $u$ objektnom i metafilozofskom jeziku filozofije, frazama metà lógou i lógon didónai Platon povezuje diskurs obrazloženja, kao dio objektnog govora filozofije, s metajezičnim pitanjima poput "stila u filozofiji” $i$ Sokratove upotrebe slikovitog neologizma "filologija" u dijalogu Teetet kojim želi izraziti bît filozofije kao misaonog rada i njezine metode. Ona, naime, ne izražava samo njegovu osobnu strast za razgovorom nego ono što razgovor jest: politički trôp mišljenja kao aktivnosti, forma društvenosti - prijateljstvo, druženje, povjerenje i predanost idealu istine kao "zajedničkog dobra svih ljudi”. ${ }^{106}$

106 Vidi Teetet 146a6-8: "Što šutite? Zar sam ja seljački neotesan što iz jezikoljublja nastojim da razgovaramo te da budemo prijatelji i međusobno složni?” Iste razloge Sokrat navodi u Harmidu 165b, 166c7d6. i mnogo drugih mjesta u ranim dijalozima u kojima se nalazi isti Sokratov apel (Lahet 19ob, 196c, 198b, 199a, 20oe; Prot. 361d; Menon 8oc; Gorgija $457 \mathrm{~d}-459 \mathrm{~b}, 470 \mathrm{c})$. 
Na takvoj osnovi, s transparentnom morfološkom strukturom, sintaktičkom određenošću i definiranim semantičkim sadržajem termina 'méthodos' - s rječničkim značenjem istraživanje uopće, te posebno, način i proces istraživanja, postupak — termin metafilozofija dopušta nam, prema svemu sudeći, nekontroverzno gledište o metamišljenju u općem i običnom smislu prirodne sposobnosti mišljenja za autoreferenciju, analognu lingvističkom pojmu metajezika. Metafilozofija kao specijalna, naime filozofska, inačica takve opće prirodne metarefleksivnosti razlikuje se od ove samo po stupnju apstraktnosti diskursa, a ne principijelno, kao što se filozofski diskurs o stvarima razlikuje od drugih modusa govora o stvarima, običnog ili kvalificiranog, samo po stupnju apstraktnosti, a ne principijelno. No, kao što smo vidjeli, dok koncept prirodne metarefleksivnosti mišljenja generira proliferaciju diskursâ u horizontalnom i vertikalnom smjeru, kroz širenje polja refleksije o uvijek novim stvarima u svijetu ili kroz povisivanje razina apstrakcije, lingvistički koncept metajezičnosti prirodnog jezika donosi, kako ćemo još vidjeti, performativni višak u stvarnosti govornika kakav sâmo mišljenje može generirati, ako uopće, tek ideelno.

No, jezično-historijska veza metafilozofije s pojmom méthodos nosi sobom nekoliko korisnih momenata za daljnju artikulaciju. Ona pruža uporište za to da prvu sistematsku, teorijsku raspravu o metafilozofiji u modernom smislu, kakav nalazimo kod suvremenih filozofa, lociramo kod ranog, još uvijek platonički nadahnutog Aristotela, u spisu Protreptikós, gdje se filozofiranje definira dvostruko:

"filozofiranjem se naziva istraživanje i sâmog toga je li nužno filozofirati ili ne (...) a također i bavljenje filozofskom teorijom." ${ }^{\text {"107 }}$

Karakteristično je pritom da Aristotel na tome mjestu za opis filozofskog mišljenja koristi, pored čestog izraza zēteîn (istraživati), glagolsku imenicu metiénai, koja sadrži elidirani prijedlog metá (met'iénai), a obično se shvaća i prevodi razvodnjenim izrazom "bavljenje" nečim. ${ }^{108}$

107 Vidi Aristotel, Fragmenta selecta (rec. Ross 1955), Protreptikós, Frgm. 2 (= Alex. Aphr. in Top. 149.9-17): фı

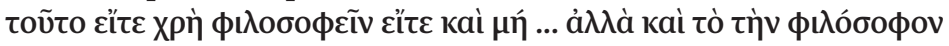

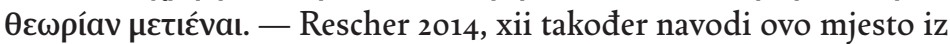
Aristotela kao izraz nužnosti meta-artikulacije filozofije, ali samo kao primjerak refleksije "vlastitog filozofskog posla" ("not self-detached", xi), ne videći njezin opći karakter.

108 Liddle-Scott-Jones, A Greek-English Lexicon, s.v. mét'eimi, inf. met'iénai sa širokim spektrom vidova osnovnog značenja slijediti/pratiti: tragati, 
No izraz metiénai, kao i méthodos, sugerira "zalaženje" (miješanje, interveniranje) mišljenja $u$ stvar, kretanje kroz stvar, stupanje tragom, upravo istraživačko prolaženje kroz, praćenje u stopu. Tu bliskost dvaju izraza posebno je uočio novokantovac Paul Natorp u svome metametodološkom članku "Kant i marburška škola" koristeći je protiv Hegelovog razumijevanja pojma méthodos:

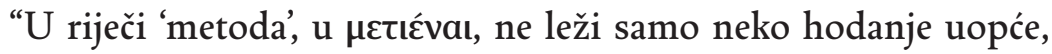
nekakvo sebe-pokretanje; niti, kako misli Hegel, puko su- i pored-hodanje, nego ona znači ići za nekim ciljem ili, u svakom slučaju, ići u sigurnom smjeru: 'ići za [čime]"."109

No, protiv takvog Natorpovog čitanja dvaju izrazâ govori nekoliko okolnosti. On uzima méthodos i metiénai kao neposredno iste i značenjski i etimološki, a prepoziciju metá tumači u oba slučaja reduktivno polazeći od rekcije u akuzativu koja pripada glagolu metiénai. Ona ga zavodi da značenje toga izraza jednostrano čita na matrici njemačkog nach-gehen (ići iza/za, slijediti, tragati za, potraživati, zahtijevati) i da ga suprotstavi Hegelovu navodno krivom shvaćanju metode kao "pukog praćenja” (njem. mitgehen, su-hodanje). Natorpovo naglašeno plastično, ali nelegitimno apozicijsko čitanje prepozicije metá u obama izrazima, imenskom méthodos i glagolskom metiénai, očigledno je metafizičko u onom smislu kakav smo već vidjeli na čitanjima pojma metafilozofije: ono polazi od vremenskog i prostornog odmaka između izvora radnje i njezinog objekta, kao da prijedlog nije sastavni dio složenice nego izolirana riječ, i štoviše, kao da nije prijedlog nego prilog vremena ili prostora u apsolutnoj upotrebi, gdje stoji za već određeni cilj kretanja ili - "u svakom slučaju, siguran smjer".

No, takvo po-sljedično čitanje ne odgovara složenoj jezičnoj upotrebi tih izraza u starogrčkom: metiénai se upotrebljava također i u su-sljednom, socijativnom značenju: ući među, zaći u, sdružiti se, zbližiti

istraživati, potraživati, progoniti.

109 Paul Natorp 1912, 199-200. Vidi diskusiju u Alan Kim 2016, "Paul Natorp", osob. dio 3. Method and Hypothesis, gdje autor upozorava na etimološku pogrešku kod Natorpa, ali prihvaća njegovo tumačenje metode u smislu traganja za distinktnim ciljem što ističe karakter kretanja na mišljenju. Usp. “(...) as Natorp correctly says, both terms signify the pursuit of something, and Natorp uses the verb to stress the movement, the action of thinking" (bilj. 18, kurziv moj). 
se, umiješati se. ${ }^{110}$ Upravo to se ne vidi samo u Aristotelovoj upotrebi izraza metiénai za definiciju filozofiranja u Protreptiku nego i na drugim mjestima. Ona je i po značenju i gramatičkoj formi analogna prvom izrazu (zēteîn) koji ima direktni objekt u akuzativu i suodređuje sintaktičku upotrebu značenjski bliskih izraza poput metiénai. Oboje su poimeničeni infinitivi za misaone radnje kojima se definira filozofiranje. Ono je najprije opisano kao istraživanje (zēteîn) čiji je predmet "nužnost samog filozofiranja”, što znači da filozofsko mišljenje in nuce istražuje sâmo sebe. To se potvrđuje time što Aristotel pojačava argument da se "nužno mora filozofirati kao i kad netko tvrdi da filozofiranje nije nužno". ${ }^{111}$ Nadalje, taj auto-imanentni aspekt filozofiranja održava se i u drugom dijelu opisa filozofiranja gdje se pojavljuje izraz metiénai: naime, kako god da razumijemo smisao prepozicije metá s akuzativom (ići među ili hodati za/iza), moramo prihvatiti, nasuprot Natorpovu nach-gehen, a u korist Hegelova mit-gehen, da objekt ili cilj radnje metiénai nisu izvanjski predmeti za kojima bi mišljenje išlo, nego ih čini sâma 'filozofska teorija'. Filozofiranje nije ništa drugo do teorijsko istraživanje filozofske teorije. ${ }^{112}$

Iz toga vidimo, filozofiranje je definirano specifično visokom teorijom, tj. teorijom principâ, i obrnuto: visoka ili filozofska theoria

110 Za osebujan spoj dvaju naoko disparatnih smislova prepozicije metá, socijativnog i sukcesivnog, u glagolu metiénai u amfiboličnom obliku su-hođenja v. Platonovu analogiju razboritog seljaka i filozofa u Fedar

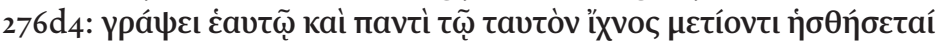
$\tau \varepsilon \theta \varepsilon \omega \rho \tilde{\omega} v$ ("pisat će samome sebi i svakome tko stupa istim tragom, i uživat će motreći”). Da ovaj stav možda ima paradigmatsku vrijednost za filozofsko istraživanje, sugeriraju rasprave o tzv. IMRaD formatu znanstvenog članka (v. prilog G. Rujevića, ovdje), posebno o socijalno "reproduktivnoj” funkciji koja, suprotno prigovorima o normativnom uniformiranju, omogućuje otvoren pristup postupcima provjere i kritike "svakome tko stupa istim tragom".

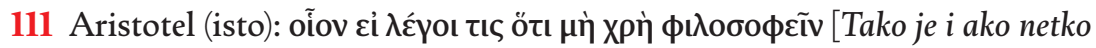
kaže da nije nužno filozofirati.]

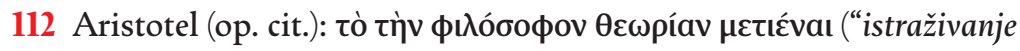
filozofske teorije”). Taj cirkularni karakter osobito plastično ističe pregnantni navod Aristotelove formule o nužnosti filozofiranja kod

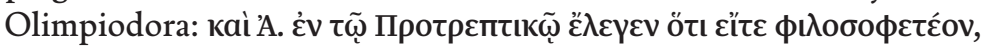
фı

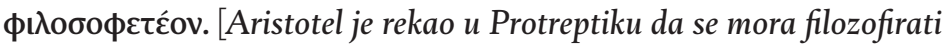
o tome mora li se filozofirati, a mora se filozofirati i o tome ne mora li se filozofirati. Svakako se mora filozofirati.] 
principâ definirana je onim $u$ što filozofiranje “zalazi”. Štoviše, upravo je ta cirkularnost ono što uopće čini filozofsku bît i čar teorije. Drugim riječima, filozofiranje je definirano iznutra 'metodom' ili putanjom mišljenja koja je dvostruka: refleksivno istraživanje vlastitog svojstva nužnosti i motrilački modus svoga postupka. To na ovom mjestu kod Aristotela rječito potvrđuju dvije jezične posebnosti izraza metiénai. Jedna je upotreba izvorno pridjevskog oblika izraza philósophos, koji se pridijeva samoj teoriji (hē philósophos theōría), a ne primarno osobi filozofa, da bi izrazio posebno svojstvo teorijskog rada. Druga je da isto značenje izraza metiénai kao intervencije u predmet, potvrđuje i apsolutna upotreba dvaju oblika glagola metiénai, poimeničenog infinitiva (tò metiénai) i glagolskog pridjeva za istraživače (hoi metióntes); u običnom jeziku ti su oblici tipičan izraz za traganje i tragače općenito, od izvidnica i izviđanja, uhoda i uhođenja, potraživanja i potraživača, do istraživanja $i$ istraživača u polju znanja. ${ }^{113}$

Na takvoj filološkoj podlozi možemo sad i sâmi 'stupati istim tragom' (metiénai) one poetske funkcije metajezika koju smo vidjeli u Hamannovoj metakritičkoj dijagnozi "slučajne sinteze jednog grčkog prijedloga”. Lingvistički pojam metajezične i ujedno autopoietičke funkcije jezika pokušat ću upotrijebiti kao komad stvarnosti, a ne samo kao analogijski explanans za pretpostavku o imanentizmu odnosa metafilozofije i filozofije. Poći ću od naprijed formulirane pretpostavke da metajezična funkcija jezika nije odgovorna samo za re-produkciju i proliferaciju diskursâ, bilo znanstvenih poput lingvistike ili književnih poput poezije, proze i esejistike, iznad razine prosječnog jezika (govora) o objektima u svijetu, nego za nešto presudnije, barem u kontekstu ove rasprave. Ona je medij za pojavu subjekta kroz jezično samoproizvođenje na istom onom mjestu "slobodnog označitelja" na kojem stoji Hamannov pojam-i-termin metakritika. Kako smo vidjeli, ona ne ponavlja Kantovu kritiku uma izdajući čiste pojmove za gramatičke kategorije, kako je slučaj kod Herdera, nego pomoću male količine elementarnih semiotičkih formi (matrices) proizvodi nove govore, poput teorijskih i poetskih diskursâ o stvarima u svijetu, kao

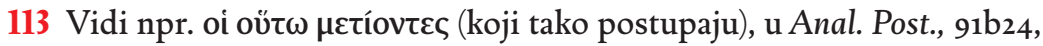
koja je semantički, leksički i retorički analogna učestaloj frazi oi

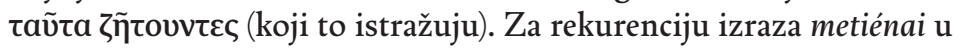
Aristotelovu opusu, s rekcijom u akuzativu (ili rjeđe s prepozicijom perí i objektom u genitivu) u značenju istraživanje nečega, ili s apsolutnom upotrebom u značenju istraživanje uopće, v. Hermann Bonitz 1870, Index Aristotelicus, 463 s.v. 
i njihova realnog subjekta iskazivanja. Metajezična i poetska funkcija jezika također je i autoperformativna za subjekt filozofije.

Autopoietičku funkciju jezika vrijedi istražiti slijedeći trag Hamannova "silaženja u rodno mjesto uma" u jeziku, nasuprot Kantovu "uspinjanju do rodnog mjesta metafizike u samom čistom umu”. Iako je Hamannovo duhovito izvrtanje Kantove formulacije o metafizici kao "slučajnoj sintezi jednog grčkog prijedloga" naoko samo aluzija običnog filološkog karaktera, njezine su implikacije dublje konceptualne naravi, a teorijske posljedice dalekosežne. Hamannova aluzija ironizira zaboravljenu i potisnutu falsifikaciju fraze metà tà physiká $\mathrm{s}$ topičkim (prostorno-relacijskim) smislom u imenicu metaphysica koja se odnosi na supstancijalne predmete i otuda čini presudan jezični događaj koji će zacrtati budućnost filozofije ili, da ponovim Natorpovu formulaciju, "siguran smjer" njezine metode. Taj događaj ne leži samo u zamjeni jedne jezične veličine (oblika, izraza, fraze, pojma i referenta) drugom, i ne samo jednog jezika drugim (grčkog latinskim), nego u redukciji jezičnih funkcija: deskriptivna potiskuje i zamjenjuje poietičku i performativnu. Upravo sam je pokušao pokazati na retorički plastičnom i ujedno doslovnom smislu pojma méthodos kako ga izražava sinonimni izraz metiénai: istraživanje se ne određuje samo s obzirom na objekt kao izvanjski predmet odnošenja ili cilj za kojim se kreće istraživanje nego je ujedno intervencija subjekta i njegov teorijski užitak. No, kako smo usput vidjeli, filozofski diskurs o svijetu i o sebi, tendira ka sistematskom prikazu pod vidom deskripcije fenomena $i$ logičke prihvatljivosti argumenata, a izbjegava poetske postupke u gradnji čak i kad ih teorijski glorificira. To čini dominantni dio povijest filozofije i najveći udio njegova literarnog korpusa u kojem su pojave poput Hamanna rijetkost, bilo to za dobro ili štetu po filozofiju.

Otud, usprkos definiciji filozofiranja u najranijem sažetom obliku u Aristotelovu spisu Protreptikós, koja emfatično iskorištava plastičnost izraza metiénai i upečatljivo afirmira, čak i s današnjeg gledišta, imanentni odnos metafilozofske refleksije i filozofskog "bavljenja stvarima”, ona se također može čitati kao opredmećujuća i za sâmu filozofiju utoliko što definira filozofiju kao teorijsko bavljenje filozofskom teorijom. Upravo je to udvostručenje filozofije kroz samoopredmećenje tipični model metafilozofije. U Aristotelovom (i Platonovom) žargonu izraz metiénai obuhvaća ili zamjenjuje druge tipične izraze za teorijski rad, poput zēteîn, sképsis, theōría, méthodos i dr., bilo u području neke posebne (filozofske) teorije, poput etike, poietike, prve filozofije, ili neodređeno i uopće. Obje razine primjene odgovaraju 
suvremenim definicijama metafilozofije, poput "filozofije filozofije" ili teorije "bilo čega drugog" (T. Williamson). No, premda su rasprave o metodi istraživanja, taj tipični oblik metafilozofije, eksplicitno zastupljene kod Platona na objektnoj razini, i to ne samo u ranim i srednjim dijalozima nego i u kasnijim dijalozima Teetet, Sofist, Državnik i Parmenid koji sustavnije i opsežnije obrađuju teme poput pouzdanog mišljenja, definicije znanja, istinitog suđenja i eksplanatorne funkcije oprimjeravanja, ipak nad zagovarateljima metafilozofije kao posebne filozofije ostaje kao Damoklov mač visiti pitanje možemo li jednostavno razlikovati metafilozofsku razinu izlaganja od objektno-diskurzivne, ako se filozofija jednako - na isti metodski način i na istom položaju predmeta - bavi sobom kao i bilo čime drugim. Što filozofsku teoriju filozofske teorije čini posebno filozofskom ako je išta čini posebno filozofskom?

O nelagodi toga pitanja dovoljno svjedoče suvremene, po svemu sudeći inkonkluzivne rasprave o različitim modelima metafilozofije, postfilozofije, antifilozofije, transfilozofije itsl. iz različitih teorijskih tradicija. No možda rječitije o tome govori okolnost da filozofi, dospjevši do rubova sustavnog problemskog diskursa o stvarima, otkriju pitanje o granicama filozofije i odnosu prema drugim znanjima i poseže za prenesenim govorom, slikom, metaforom, jakim poetskim izričajem. Takve nisu samo Wittgensteinove ljestve ili Hegelova sova ili manje laskave metafore, nego metafora ljubavi u sâmom pojmu filozofije. Ona ne potječe iz dijaloga posvećenog teoriji erosa, koji je obesnažuje gotovo do razine doslovne upotrebe, nego iz teorije diskursâ u Fedru, kao što analogni neologizam filologija u Teetetu djeluje kao metafora za metodu u teoriji znanja, a ne u teoriji jezika u Kratilu na čijoj podlozi bi također izblijedila do doslovnog značenja. No, kako smo vidjeli na pojmu metode kod Aristotela, koji se nedvojbeno trudio da iz sistematskog diskursa filozofije izbaci Platonove metafore kao "praznoslovlje" (kenología), izbljeđivanje metaforičkog karaktera izraza méthodos kroz njegovo terminološko ustaljivanje u žargonu filozofije nije ujedno prekinulo liniju asocijacije na slikovitiji izraz traganja (metiénai).

Čini se da već to dostatno motivira interes da se jezično-filozofsko porijeklo metafilozofije, na kojem je osobito inzistirala analitička tradicija, istraži dosljednije i radikalnije, ne samo s onu stranu semantike i logike ili također i poetike, semiotike i hermeneutike, nego u smjeru analize koja će moći tematizirati složenije neobjektivirajuće aspekte diskursa filozofije o "samoj sebi", poput tvorbenog umjesto 
samo ekspresivnog, poietičkog umjesto poetskog, performativnog umjesto konstativnog, komunikativnog umjesto samo subjektivno autoreferencijalnog. Takav ću pokušati prikazati u monografskom prilogu o Sokratu. II 


\section{REFERENCE}

Adorno, Theodor W. 1956, Metakritik der Erkenntnistheorie, Frankfurt a. M.: Suhrkamp, 1956; 1970 (GS Bd. 5, 1990); engl. Against Epistemology: A Metacritique, Blackwell 1982; Polity, 2013.

Ambrose, Alice 1967, "Linguistic Approaches to Philosophical Problems", in: Richard Rorty ed., The Linguistic Turn. Essays in Philosophical Method, Chicago and London: The University of Chicago Press, 1967 (2nd ed. 1992 With two Retrospective Esssays).

Aristotel, Protreptikós, u: Aristotelis Fragmenta Selecta, rec. W. D. Ross, Oxford UP, 1955. (Njem. izd. Der Protreptikos des Aristoteles. Einleitung, Text, Übersetzung und Kommentar von Ingemar Düring, Frankfurt am Main: Vittorio Klostermann 1969 (Klostermann Texte Philosophie); hrv. "Nagovor na filozofiju” u: Aristotel, O duši/Nagovor na filozofiju, Zagreb: Naprijed, 2. izd. 1987, preveo Darko Novaković.)

Assoun, Paul-Laurent 1976, Freud, la philosophie et les philosophes, Paris: PUF, 1976.

Assoun, Paul-Laurent 2013, La métapsychologie, Paris: Presses Universitaire de France.

Badiou, Alain 2001, "Who is Nietzsche?", Pli. The Warwick Journal of Philosophy 11 (2001).

Barnes, Jonathan 1993 (1975), Aristotle: Posterior Analytics, Translated with a Commentary, 2nd ed. Oxford: Clarendon Press (Clarendon Aristotle Series).

Bayer, Oswald 2002, Vernunft ist Sprache. Hamanns Metakritik Kants, Stuttgart-Bad Canstatt.

Bayer, Oswald 2012 (1988), A Contemporary in Dissent. Johann Georg Hamann as Radical Enlightener, Grand Rapids (Michigan): W.B. Eerdmans Publishing Company (njem. Ein Zeitgenosse im Widerspruch. J. G. Hamann als radikaler Aufklärer, München: Piper Verlag, 1988).

Bayer, Oswald 2013, "Wider die Sprachvergessenheit transzendentaler Vernunftkritik. Eine Einführung in Hamanns Metakritik über den Purismum der Vernunft', u Marion Heinz, (Hrsg) 2013, Herders 'Metakritik'. Analysen und Interpretationen, Stuttgart-Bad Canstatt, 65-79.

Beck, Lewis W. 1978, “Toward a Meta-Critique of Pure Reason”, u: Essays on Kant and Hume, New Haven: Yale University Press.

Beiser, Frederick C. 1987, The Fate of Reason. German Philosophy from Kant to Fichte, Harvard University Press.

Berlin, Isaiah 2013, The Critics of Enlightenment: Vico, Hamann, Herder, Princetom University Press. 
Betz Hull, Margaret 2002, The Hidden Philosophy of Hannah Arendt, LondonNew York: RoutledgeCurzon (Routledge Jewes Studies)

Betz, John R. 2008, After Enlightenment. The Post-Secular Vision of J. G.

Hamann, Wiley-Blackwell.

Boag, Simon (2017), Metapsychology and the Foundations of Psychoanalysis.

Attachment, Neuropsychoanalysis, and Integration, London and New York:

Routledge.

Bonitz, Hermann 1870, Index Aristotelicus, repr. Graz: Akademische Verlagsantalt, 1955.

Bosteels, Bruno 2008, "Radical Antiphilosophy”, Filozofski vestnik, Vol. XXIV,

No. 2 (2008), 155-187.

Bosteels, Bruno 2011, Introduction to Alain Badiou, Wittgenstein's

Antiphilosophy, London: Verso, 2011, 1-66.

Brenner, Charles 1980, "Metapsychologie and Psychoanalytic Theory",

Psychoanalytic Quarterly 49.2, 189-214.

Bronner, Stephen E. 2017, "Critical Theory and Resistance: On

Antiphilosophy and the Philosophy of Praxis", u Michael J. Thompson

(ed.), The Palgrave Handbook of Critical Theory, New York: Palgrave

Macmillan, 2017, 17-42.

Bynum, Terrell Ward (2011), “Creating the Journal Metaphilosophy”, u: The

Future of Philosophy. Metaphilosophical Directions for the Twenty-First

Century, Metaphilosophy 42 (3), 186-190.

Carlisle, Clare and Jonardon Ganeri ed. 2010, Philosophy as Therapeia, Royal

Institute of Philosophy Supplements 66, Cambridge UP.

Cath, Yuri 2016, "Metaphilosophy”, Oxford Bibliographies,

https://www.oxfordbibliographies.com/view/document/obo-

9780195396577/obo-9780195396577-0074.xml.

Clemens, Justin 2013, Psychoanalysis is an Antiphilosophy, Edinburgh:

Edinburgh University Press.

Derrida, Jacques 1972, “La pharmacie de Platon”, u: La dissémination, Paris:

Seuil, 257-403 (izvorno Tel Quel, No. 32-33, 1968).

Feuer, Lewis S. 1959, “The Bearing of Psychoanalysis Upon Philosophy”,

Philosophy and Phenomenological Research, Vol. 19, No. 3 (1959), 323-340.

Forster, Michael N. 2010, After Herder. Philosophy of Language in the German

Tradition, Oxford: Oxford University Press.

Forster, Michael 2012, "Kant's Philosophy of Language”, Tijdschrift voor

Filosofie, 74/2012, p. 485-511.

Forster, Michael N. 2013, German Philosophy of Language. From Schlegel to

Hegel and Beyond, Oxford: Oxford University Press. 
Frank, Manfred (Hg.) 1991, Selbstbewusstseinstheorie von Fichte bis Sartre, Frankfurt a. Main: Suhrkamp (stw 964)

Frank, Manfred (Hg.) 1994, Analytische Theorien des Selbstbewusstseins, Frankfurt a. Main: Suhrkamp (stw 1151).

Frank, Manfred 1984, Was ist Neostrukturalismus?, Frankfurt a. Main: Suhrkamp.

Freud, Sigmund 1909, "Bemerkungen über einem Fall der Zwangsneurose”, Gesammelte Schriften, Bd. VIII, Leipzig, Wien, Zürich 1924.

Freud, Sigmund 1913, "Das Interesse an der Psychoanalyse”, Darstellungen der Psychoanalyse, Frankfurt a. M. Fischer Verlag 1969 (repr. 1977) [= GS Bd. IV., 311-343, 1924)

Freud, Sigmund 1915, Vorlesungen zur Einführung in die Psychoanalyse, Gesammelte Schriften, Bd. VII, Leipzig, Wien, Zürich 1924.

Gakis, Dimitris 2012, Contextual Metaphilosophy. The Case of Wittgenstein, Amsterdam: ILLC Dissertation Series DS-2012-06.

Ganeri, Jonardon 2001, The Proper Work of Reason. Philosophy in Classical India, London: Routledge.

Gattei, Stefano 2008, Thomas Kuhn's "Linguistic Turn" and the Legacy of Logical Empiricism. Incommensurability, Rationality and the Search for Truth, Hampshire: Ashgate.

Griswold, Charles L. Jr. 1988, “Plato’s Metaphilosophy”, u: Charles L. Griswold Jr. (ed.), Platonic Readings, Platonic Writings, The Pennsylvania State University Press (2nd ed. 2002).

Green, André 2005, "The illusion of common ground and mythical pluralism”, International Journal of Psychoanalysis, 86, 627-632.

Groys, Boris 2012, Introduction to Antiphilosophy, London: Verso (njem. izv. Einführung in die Anti-Philosophie, Hanser Verlag, 2009).

Hacking, Ian 1975, Why Does Language Matter to Philosophy?, Cambridge University Press.

Hadôt, Pierre 1995, Philosophy as a Way of Life. Spiritual Exercises from Socrates to Foucault, Oxford UK-Cambridge USA: Blackwell.

Hamann, Johann Georg 1784 [1825], "Metakritik über den Purismus der Vernunft”, u Hamann's Schriften. Siebenter Band, hrsg. von Friedrich Roth, Leipzig: G. Heimer, 1825. (Sämtliche Werke, hrsg. v. Josef Nadel Wien 1951, Bd. 3, 281-289; J. G. Hamann, Briefwechsel. Fünfter Band, 1783-1785. hrsg. v. Arthur Henkel. Frankfurt 1965, S. 210-216.) Engl. prijevod "Metacritique on the Purism of Reason", u J. G. Hamann, Writings on Philosophy and Language, ed. by Kenneth Haynes, Oxford University Press, 2007, 205-218. 
Hartmann, Eduard v. 1869, Philosophie des Unbewussten I-III, Berlin: Carl

Duncker's Verlag, 7. erweiterte Auflage 1876.

Hegel, G.W.F. 1828 (1986), “Hamanns Schriften”, u: G. W. F. Hegel, Werke in 20 Bänden, Bd. 11, Berlinger Schriften (Redaktion E. Moldenhauer und K.

M. Michel), Frankfurt a. Main: Suhramp, 1986, 275-352.

Heinz, Marion (Hrsg) 2013, Herders 'Metakritik'. Analysen und Interpretationen, Stuttgart-Bad Canstatt (problemata 154).

Herder, Johann G. 1772, "Abhandlung über den Ursprung der Sprache”, Sämtliche Werke, Bd. V, hrsg. von Bernhard Suphan, Hildesheim: Georg Olms Verlagsbuchhandlung 1967 (reprographischer Nachdruck der Ausgabe Berlin 1891); engl. prijevod J. G. von Herder, “Treatise on the Origin of language", Philosophical Writings, translated and edited by Michael N. Forster, 2004.

Herder, Johann G. 1799, Verstand und Erfahrung. Eine Metakritik zur Kritik der reinen Vernunft. Erster Theil; Vernunft und Sprache. Eine Metakritik zur Kritik der reinen Vernunft. Zweiter Theil, Frankfurt und Leipzig 1799 (Classic Reprint, 2017).

Holt, Robert R. 2002, “Metapsychology”, u: E. Erwin (ed.), The Freud Encyclopedia: Theory, Therapy and Culture, New York: Routledge, 337-341. Horwitch, Paul 2013, Wittgenstein's Metaphilosophy, Oxford: Clarendon Press. HWPh (Historisches Wörterbuch der Philosophie in zwölf Bänden), hrsg. von J. Ritter, K. Gründer, G. Gabriel, Basel: Schwabe Verlag, 1971-2007 (CDRom 2010; online 2017), Bd. 9, 1995.

Ichikawa, Jonathan (ed.) 2019, “Metaphilosophy”, https://philpapers.org/ browse/

Iribadjakov, Nikolai 1974, "Philosophy and Antiphilosophy", Philosophy and Phenomenological Research, Vol. 35, No. 2 (Dec., 1974), 181-200.

Jakobson, Roman 1985 (1956), "Metalanguage as a linguistic problem”, Selected Writings, VII, Edited by S. Rudy, The Hague: Mouton, 113-121.

Jaworski, Adam, Nicolas Coupland, Dariusz Galacinski ed. 2004,

Metalanguage. Social and Ideological Perspectives, The Hague: Mouton de Gruyter.

Joll, Nicholas 2017, "Metaphilosophy”, Internet Encyclopedia of Philosophy, https://www.iep.utm.edu/con-meta/.

Kangrga, Milan 2010, Spekulacija i filozofija. Od Fichtea do Marxa, Beograd: Službeni glasnik.

Kant, Immanuel 1783 [1920], Prolegomena zu einer jeden künftigen Metaphysik, die als Wissenschaft wird auftreten können, hrsg. von Karl Vorländer, Leipzig: Verlag von Felix Meiner, 6. Auflage 1920 (Akademie-Ausgabe, Bd. 4, Berlin 1904/1911). 
Kim, Alan 2016, "Paul Natorp", The Stanford Encyclopedia of Philosophy, URL: https://plato.stanford.edu/archives/sum2016/entries/natorp/

Krstić, Predrag 2015, "Neželjeno roditeljstvo: romantizam i Kant”, u: Kant $i$ romantizam, Filozofija i društvo, vol. 26, 1, 2015, 88-108.

Lazerowitz, Morris 1964, Studies in Metaphilosophy, London: Routledge and Kegan Paul.

Lazerowitz, Morris 1970, Note on 'Metaphilosophy', u: Metaphilosophy, 1, 1970.

Lazerowitz, Morris 1977, “Metaphilosophy”, u: The Language of Philosophy. Freud and Wittgenstein, Dordrecht-Boston: Reidel Publishing Company (Synthese Library, Vol. 117), pp. 1-17 (izvorno u Crítica. Revista Hispanoamericana de Filosofía, Vol. 5, No. 15 (Sept. 1971), 3-27.

Lefèbvre, Henry 1965, Métaphilosophie, Paris: Minuit, 2. izdanje Editions Syllepse 2001; engl. Metaphilosophy, London: Verso 2016.

Lenz, Martin 2010, Lockes Sprachkonzeption, Berlin: de Gruyter. Locke, John 1690 (1975), An Essay Concerning Human Understanding, ed. by Peter H. Nidditch, The Clarendon Edition of the Works of John Locke. LSJ = Liddle-Scott-Jones 1982, A Greek-English Lexicon. With a Supplement 1968 by S. McKenzie, Oxford: Clarendon Press.

Lüpke, Johannes 2004, “Ohne Sprache keine Vernunft. Eine Einführung in das Sprachdenken Johann Georg Hamanns”, Neue Zeitschrift für systematische Theologie [NZSTh], 46. Bd., 1-25 .

Matilal, Bimal K. 2005, Epistemology, Logic and Grammar in Indian Philosophical Analysis, ed. by J. Ganeri Oxford UP (1st ed. 1970).

McRae, Robert 1988, "Locke and Leibniz on Linguistic Particles”, Synthese, Vol. 75, No. 2,. 155-161.

Mikulić, Borislav 2017, “Osjetilna izvjesnost i jezik: Hegel, Feuerbach i jezični materijalizam”, u Inačice materijalizma, ur. B. Mikulić i M. Žitko, Zagreb: Filozofski fakultet Sveučilišta u Zagrebu (Edicija Radovi Odsjeka za filozofiju, knj. 2).

Mikulić, Borislav 2019, "Čovjek ali najbolji. Romi u žrvnju radne, bilološke i jezične definicije rase”, Narodna umjetnost 56/2, 7-39.

Mladenović, Bojana 2017, Kuhn's Legacy. Epistemology, Metaphilosophy, and Pragmatism, New York: Columbia University Press.

Morrow, David R. and Chris Alen Sula 2011, "Naturalized metaphilosophy”, Synthese, Vol. 182, No. 2, Representing Philosophy (Sept. 2011), 297-313.

Moser, Paul K. (1999). “Metaphilosophy”, u: Robert Audi (ed.) 1999, The Cambridge Dictionary of Philosophy, Cambridge MA: Cambridge University Press, 1999 (2nd edition), 561-562. 
Natorp, Paul 1912, "Kant und die Marburger Schule”, Kant-Studien 17, 193-221.

Nietzsche, Friedrich 1882, Die fröhliche Wissenschaft, u Sämtliche Werke, G. Colli und M. Montinari (Hrsg.), KSA Bd. 3, Berlin: DTV, de Gruyter.

Nozik, Robert 1981, Philosophical Explanations, Cambridge (Mass.): Harvard UP.

Overgaard, Søren, Paul Gilbert, and Stephen Burwood 2013, Introduction to Metaphilosophy, Cambridge University Press.

Prole, Dragan 2004, "Metakritika ili parodija? Aktuelnost Herderove interpretacije Kanta”, Arhe 1: 2004, 177-193.

Pupi, Angelo 1980-81, “Tradizione e presenza del pensiero di J. G. Hamann”, Rivista di Filosofia Neoscolastica, No. 72-73.

Pupi, Angelo 1999, Introduzione, traduzione e note, u: J. G. Hamann, Memorabili Socratici., Santarcangelo di Romagna: Rusconi Libri 1999.

Radhakrishnan, Sarvepalli ed. 1953, The Principal Upaniṣads. Edited with Introduction, Text, Translation, and Notes by S. Radhakrishnan, London: Allen and Unwin.

Razinski, Liran 2016, "On the Need for Openess to the Humanities in Psychoanalysis”, Psychoanalytic Psychology, Vol. 33 (Suppl. 1), S56-S71.

Reese, William L. 1990, "Morris Lazerowitz and Metaphilosophy", Metaphilosophy, Vol. 21, No. 1/2 (January/April 1990), 28-42.

Rescher, Nicholas 2006, Philosophical Dialectics. An Essay on Metaphilosophy, New York: SUNY Press.

Rescher, Nicholas 2007, Interpreting Philosophy. The Elements of Philosophical Hermeneutics, Frankfurt/Paris/Ebicon/Lancaster: Ontos Verlag.

Rescher, Nicholas 2010, Philosophical Inquiries. An Introduction to Problems of Philosophy, University of Pittsburg Press

Rescher, Nicholas 2014, Metaphilosophy: Philosophy in Philosophical Perspective, Lanham/New York/London: Lexington Books.

Rorty, Richard 1967, "Metaphilosophical Difficulties of Linguistic

Philosophy”, in: Richard Rorty ed., The Linguistic Turn. Essays in Philosophical Method, Chicago and London: The University of Chicago Press, 2nd. ed. 1992 (With two Retrospective Esssays).

Rowe, M. W. 2007, "Wittgenstein, Plato, and the Historical Socrates",

Philosophy vol. 82, No. 319 (2007), 45-85.

Schwemmer, Oswald 1997, Ernst Cassirer, Berlin: De Gruyter.

Seebohm, Thomas M. 1972, "Der systematische Ort der Herderschen Metakritik”, Kant-Studien 63 (1-4), 59-73.

Staal, Frits 1975, “The Concept of Metalanguage and Its Indian Background”, Journal of Indian Philosophy, 3 (1975), 315-354. 
Surber, Jere O. 2006, Introduction, u: Hegel and Language, ed. by J. O’Neill Suber, New York: SUNY Press, 1-14.

Vlaški, Stanko 2015, "Transcendentalna filozofija u perspektivama romantičarske fragmentarnosti”, u: Kant i romantizam, Filozofija i društvo, vol. 26, 1, 2015, 69-87.

Wallerstein, Robert 2005, "Will psychoanalytic pluralism be an enduring state of our discipline”; "Dialog or Illusion? How do we go from here? Response to André Green”, International Journal of Psychoanalysis, 86, 623-626, 633-638.

Ware, Robert B. 1996, "Hegel's Metaphilosophy and Historical Metamorphosis", History of Political Thought, Vol. 17, No. 2 (Summer 1996), 253-279.

Wharton, Kate 2010, “The Teacher as Mother or Midwife? A Comparison of Brahminical and Socratic Methods of Education”, in C. Carlisle and J. Ganeri ed., Philosophy as Therapeia, Royal Institute of Philosophy Supplement 66, Cambrige University Press, 103-117.

Wohlfahrt, Günter 1984, "Hamanns Kantkritik”, Kant-Studien, Bd. 75, Heft 1-4, 398-419 (izvorno: Denken und Sprache, Freiburg/München: Karl Alber Verlag 1984, Kapitel 2).

Williamson, Timothy 2007, The Philosophy of Philosophy, Blackwell Publishers.

Williamson, Timothy 2018, Doing Philosophy. From Common Curiosity to Logical Reasoning, Oxford University Press. 